\title{
Sulfate Resistance in OPC and SRPC Containing Calcined Paper Sludge Waste: Ettringite or Thaumasite Formation
}

\author{
Rafael Talero, Ph.D. ${ }^{1}$; Carlos Arámburo²; Mariano González, Ph.D. ${ }^{3}$; M. I. Sánchez de Rojas, Ph.D. ; \\ Antonio Blázquez, Ph.D. ${ }^{5}$; Moisés Frías, Ph.D. ${ }^{6}$; and César Pedrajas, Ph.D. ${ }^{7}$
}

\begin{abstract}
The Le Chatelier-Anstett test was used to study the sulfate resistance of cement pastes containing calcined paper sludge waste (MC). MC was blended with two types of portland cement (PC): P1 with and P2 without $\mathrm{C}_{3} \mathrm{~A}$ (ordinary portland cement, $\mathrm{OPC}$, and sulfateresistant portland cement, SRPC, respectively). The study of thaumasite formation required the utilization of a third PC, P3. The results showed that sulfate resistance always decreased at higher ratios of PC replacement by $\mathrm{MC}$. This behavior was attributable to the expansive synergic effect (ESE), originated by the coprecipitation of ettringite from two resources in a gypsum and water medium. Part of the ettringite formed rapidly from the $\mathrm{Al}_{2} \mathrm{O}_{3}^{r-}$ in $\mathrm{MC}$, and rapidly or slowly from the $\mathrm{C}_{3} \mathrm{~A}$ in $\mathrm{P} 1$, depending on whether its early pozzolanic activity was sufficient or not. Rapid-forming ettringite of both origins was induced by the sufficient specific, fast, and early pozzolanic activity resulting in the indirect stimulation of sulfate-mediated P1 hydration (its $\mathrm{C}_{3} \mathrm{~A}$ content especially) by the metakaolin present in the MC. Where such activity was insufficient, however, slow-forming ettringite was generated, reducing the ESE. The substantial calcite content in MC also played a very significant role in ESE, the result of the stimulation of such hydration, concomitant sulfate attack, and thaumasite formation. Stimulation was both direct (due to initial particle moistening by the mixing water) and nondirect (due, at the very outset, to the positive and negative electrostatic charge acquired by their particles during grinding and/or mixing, and subsequently, to the zeta potential originated as PC hydration progressed). Lastly, calcite (natural or synthesized in portlandite carbonation) was shown to be needed for thaumasite to form, a process not confined solely to low-temperature environments.
\end{abstract}

Author keywords: Portland cements; Calcined paper sludge waste; Sulfate attack; Ettringite; Thaumasite.

\section{Introduction}

Mineral additions have been used in portland cement (PC) for many years. Essentially, two types may be ground into portland clinker or blended directly with the portland cement: pozzolanic additions (natural and artificial—fly ash especially_pozzolans) or hydraulically active mineral additions (slag blast furnace) and crystalline fillers.

The greater or lesser effect of pozzolans on portlandite $\left[\mathrm{Ca}(\mathrm{OH})_{2}\right]$, depends primarily on their amorphism, structure, and

\footnotetext{
"Eduardo Torroja" Institute for Construction Sciences, Serrano Galvache, 4, 28033 Madrid, Spain (corresponding author). E-mail: rtalero@ietcc.csic.es

${ }^{2}$ Cementos ARGOS, S.A., Laboratorio de Control Calidad, Carrera 19, \#12132, Yumbo, Valle del Cauca, Medellín, Colombia. E-mail: caramburo@argos.com.co

${ }^{3}$ Escuela Técnica Superior de Ingeniería de la Edificación, Avda. Juan de Herrera, 6, 28040 Madrid, Spain. E-mail: mariano.gonzalezc@upm.es

4"Eduardo Torroja" Institute for Construction Sciences, Serrano Galvache, 4, 28033 Madrid, Spain. E-mail: srojas@ietcc.csic.es

5"Eduardo Torroja" Institute for Construction Sciences, Serrano Galvache, 4, 28033 Madrid, Spain. E-mail: blazquez@ietcc.csic.es

6"Eduardo Torroja" Institute for Construction Sciences, Serrano Galvache, 4, 28033 Madrid, Spain. E-mail: mfrias@ietcc.csic.es

7"Eduardo Torroja" Institute for Construction Sciences, Serrano Galvache, 4, 28033 Madrid, Spain. E-mail: cpedrajas@ietcc.csic.es
}

reactivity (Mehta 1983; Talero 1990). The cement industry has gradually adopted the practice of enhancing their product not only with pozzolans, but also with crystalline mineral additions known as fillers, some of which interact physically, chemically, or both with portland cement (Mehta and Monteiro 1993; Rahhal and Talero 2005; Rahhal et al. 2012).

Prior studies (Frías et al. 2008a, b; García et al. 2008, 2010; Rodríguez et al. 2008) ascertained the chemical, physical, and mineralogical properties of paper industry waste (MC) calcined at $650^{\circ} \mathrm{C}$ for $2 \mathrm{~h}$ (Frías et al. 2008a) for subsequent use as a pozzolanic addition to portland cement.

When so calcined in the presence of calcite, the kaolin fraction in the starting material is dehydroxylated, producing metakaolin. All the studies conducted on MC confirm its beneficial effect on the chemical resistance (Frías et al. 2008a, b; García et al. 2008, 2010; Rodríguez et al. 2008), rheology (García et al. 2008, 2010), and mechanical strength (García et al. 2008; Rodríguez et al. 2008) of the resulting blended cement.

The pozzolanic properties of metakaolin have been studied in depth in building material applications (Talero and Rahhal 2009; Murat 1983a, b; Murat and Comel 1983; Talero 1986; de Silva and Glasser 1990, 1993). Metakaolin is obtained by calcining kaolin or paper industry waste (Resmini et al. 2012), to which slaked lime is sometimes added (Murat 1983a, b; Murat and Comel 1983; de Silva and Glasser 1993). According to Talero (1986), chemically speaking, metakaolin is an aluminic pozzolan in chemical character [due to its high reactive alumina content, $\mathrm{Al}_{2} \mathrm{O}_{3}^{r-}(\%)$ ], although further to the provisions of ASTM C618-08 Standard (ASTM 2008), it is both siliceous and aluminous in nature.

Further to Trusilewicz et al. (2012), the reactive alumina of pozzolans, whose physical state may be amorphous and/or vitreous, 
is defined as a fraction of tetra-coordinated or penta-coordinated aluminum oxide $\left(\mathrm{Al}_{2} \mathrm{O}_{3}^{r-}\right)$ organized in a $\chi$-alumina-like structure. PC-AFt phase formation:

$$
\mathrm{C}_{3} \mathrm{~A}+3 \mathrm{CaSO}_{4} \cdot 2 \mathrm{H}_{2} \mathrm{O}+25 \mathrm{H}_{2} \mathrm{O} \rightarrow \mathrm{C}_{3} \mathrm{~A} \cdot 3 \mathrm{CaSO}_{4} \cdot 31 \mathrm{H}_{2} \mathrm{O}
$$

Molar vol. $88.8 \rightarrow 714.7$

Volume ratio $1 \rightarrow 8.0$

Pozzolan-AFt phase formation:

$$
\begin{aligned}
& \mathrm{Al}_{2} \mathrm{O}_{3}^{r-}+3 \mathrm{CaO}+3 \mathrm{CaSO}_{4} \cdot 2 \mathrm{H}_{2} \mathrm{O} \\
& +25 \mathrm{H}_{2} \mathrm{O} \rightarrow \mathrm{C}_{3} \mathrm{~A} \cdot 3 \mathrm{CaSO}_{4} \cdot 31 \mathrm{H}_{2} \mathrm{O}
\end{aligned}
$$

Molar vol. 29.1 $\left(=\gamma-\mathrm{Al}_{2} \mathrm{O}_{3}\right.$ molar volume which does not

hold for $\left.\mathrm{Al}_{2} \mathrm{O}_{3}^{r-}\right) \times 714.7$

Volume ratio $128.3^{2 *}$ (Further to*, this value must be

even greater than 28.3 )

In the absence of sulfates, however, aluminic pozzolans raise mechanical strength, especially early age strength (Mejía 1997; Mejía et al. 2003), and prevent or at least hinder chloride attack on the steel in reinforced concrete, first chemically, and then physical-chemically, but the protective chemical aspect holding priority always (Mejía 1997; Mejía et al. 2003; Talero et al. 2011; Talero 2012).

Silicic pozzolanic additions (diatomaceous earth, opaline stones, ash from the controlled incineration of the stem and rice husk, bagasse from sugar cane, from bamboo, etc.), in contrast, when suitably dosed with each PC, raise sulfate resistance (Talero and Rahhal 2009; Talero 1986, 2013; Martín-Luengo 1997) but favor chloride attack on steel reinforcement (Mejía 1997; Mejía et al. 2003) and reduce the mechanical strength of the portland cement with which they are blended (Mejía 1997; Mejía et al. 2003; Talero 2013; Rahhal and Talero 2009a). The exception in this regard is silica fume, which raises both sulfate resistance and mechanical strength (Mejía et al. 2003; Talero et al. 2011; Talero 2012, 2013; Martín-Luengo 1997; Rahhal and Talero 2009a; Rahhal et al. 2007), while hindering chloride ion ingress both physically and chemically as well. Here, the protective mechanism is both physical and physical-chemical, although given the morphology, small particle size, and very high reactive silica content $\left[\mathrm{SiO}_{2}^{r-}(\%)\right]$ of these artificial pozzolanic additions, the physical effect prevails (Talero 2011a, c, 2012, 2013; Mejía 1997; Mejía et al. 2003; Martín-Luengo 1997). This protective mechanism is due to its very special and particular pozzolanic activity developed when it reacts with the $\mathrm{Ca}^{2+}$ and $\mathrm{OH}^{-}$ions, respectively, of the portlandite-forming C-S-H gels (subsequently transformed into tobermorites), when it reacts with $\mathrm{Ca}^{2+}$ ions, and silanol groups, $\mathrm{Si}-\mathrm{OH}$ (later converted into hydrated silicic acid which reacts also with portlandite forming more C-S-H gels finally), when reacts with $\mathrm{OH}^{-}$ions-, which is an obstacle for the formation of ett-lf of $\mathrm{C}_{3} \mathrm{~A}$ origin from PC. In addition, if their concretes and mortars are submitted to adequate water curing before each aggressive attack referred, their protective effect is greater yet.

All other pozzolanic additions, including natural pozzolans (Rahhal 2002; Rahhal and Talero 2010), fly ash (Rahhal and Talero 2009b), and similar substances (Binifi et al. 2012), lie between these two extremes, with properties that depend on their reactive fraction: i.e., they are either silicic-aluminic because their reactive silica $\left[\mathrm{SiO}_{2}^{r-}(\%)\right]$ and reactive alumina $\left[\mathrm{Al}_{2} \mathrm{O}_{3}^{r-}(\%)\right]$ contents are such that they are more silicic than aluminic in chemical character or the contrary, they will be aluminic-silicic for the analogous reason. The foregoing is irrespective of their siliceous and aluminous nature further to ASTM C618-08a (ASTM 2008).
Sulfates are the most aggressive natural agents affecting cement matrices. Consequently, most industrialized countries have established chemical-physical specifications [ASTM C150-14 (ASTM 2014); EN 197-1 (AENOR 2011)] to guarantee suitable cement resistance to these ions. Where such chemical-physical specifications are absent, however, accelerated attacks must be simulated, using methods such as the Le Chatelier-Anstett test (L-A) (Blondiau 1961; Talero 2002).

In another vein, thaumasite formation is also an acknowledged cause of deterioration in portland cement-based products. According to the literature, its appearance in mortar and concrete may be attributed to one of two mechanisms (Bensted 2003; Crammond 2003). In the first, it is assumed to be the result of the replacement of the $\mathrm{Al}^{3+}$ ions in ettringite with $\mathrm{Si}^{4+}$ ions, and of the interstitial substitution of $\left[\left(\mathrm{SO}_{4}^{2-}\right)_{2} \cdot\left(\mathrm{CO}_{3}^{2-}\right)_{2}\right]$ for $\left[\left(\mathrm{SO}_{4}^{2-}\right)_{3} \cdot\left(\mathrm{H}_{2} \mathrm{O}\right)_{2}\right]$. Further to the second, it is the result of the interaction between sulfate and carbonate ions and C-S-H gel. The use of limestone fillers as cement mineral additions, which has been on the rise since 1980, has driven the study of thaumasite formation in concretes exposed to sulfate environments (Talero 2002). Its formation has been shown to rise substantially at temperatures below $15^{\circ} \mathrm{C}$. The literature reports that even concrete made with sulfate-resistant portland cement (Skaropoulou et al. 2009; Nobst and Stark 2003; Collet et al. 2004; Sims and Huntley 2004; Liu et al. 2013; Damidot et al. $2004 \mathrm{a}, \mathrm{b})$ is vulnerable to thaumasite sulfate attack. The two possible origins of this attack are summarized in a later discussion.

In light of the foregoing, information is needed on the behavior of cement pastes containing calcined paper sludge waste (MC) when exposed to sulfate ions. The first objective of the present study was consequently to explore sulfate resistance in two mineralogically different portland cements when blended with MC waste. The secondary objective was to try to identify the possible cause(s) of thaumasite formation.

\section{Materials and Methodology}

The materials used are described below.

1. Paper sludge waste (MC) activated at $650^{\circ} \mathrm{C}$ for $2 \mathrm{~h}$ (Frías et al. 2008a): its chemical composition, density, Blaine specific surface (BSS), and other physical properties are listed in Table 1 . Note that its calcite content was $66 \%$ by weight, whereas the metakaolin fraction accounted for approximately $33 \%$ by weight. The remaining approximately $1 \%$ comprised illite and poorly crystallised quartz (Frías et al. 2008a, b; García et al. 2010; Rodríguez et al. 2008). The chemical analysis was determinate by X-ray fluorescence (XRF). The reactive silica $\left[\mathrm{SiO}_{2}^{r-}\right.$ $(16.17 \%)]$ and reactive alumina $\left[\mathrm{Al}_{2} \mathrm{O}_{3}^{r-}(9.67 \%)\right]$ contents of $\mathrm{MC}$ were respectively determined with the Spanish standard UNE 80-225 (AENOR 2012) and Florentín (Taylor 1990) procedures.

2. The three portland cements used, P1, P2, and P3, had different crystalline composition values, as shown in Table 1: $14.11 \%$ $\mathrm{C}_{3} \mathrm{~A}$ in $\mathrm{P} 1$, an ordinary $\mathrm{PC}, \mathrm{OPC}[\mathrm{RC}-75$ (Ministerio de Obras Poblicas 1975); RC-08 (Ministerio de Fomento 2008)], and $0.00 \% \mathrm{C}_{3} \mathrm{~A}$ in $\mathrm{P} 2$ and $\mathrm{P} 3$, sulfate-resistant portland cements, (SRPCs) [RC-75 (Ministerio de Obras Poblicas 1975); RC-08 (Ministerio de Fomento 2008)]. All three PCs, manufactured from portland clinker, contained natural ground gypsum as a setting regulator. Blended cements were prepared by replacing the PC with the following proportions of MC: $80 / 20,70 / 30$, and 60/40. All the cements were blended for 30 min with a Turbula mixer (Glen Mills, Clifton, New Jersey) to obtain a sufficiently homogeneous product. Sulfate resistance was assessed in all three unblended PCs and in the P1/MC and P2/MC blends. 
Table 1. Physicochemical Characteristics of Portland Cements and Calcined Paper Sludge Waste

\begin{tabular}{|c|c|c|c|c|}
\hline \multirow[b]{2}{*}{ Parameter (\%) } & \multicolumn{3}{|c|}{ Portland cement (PC) } & \multirow{2}{*}{$\begin{array}{c}\text { Calcined paper } \\
\text { sludge waste }\end{array}$} \\
\hline & P1 & $\mathrm{P} 2$ & P3 & \\
\hline L.O.I. & 1.60 & 1.11 & 1.64 & 23.21 \\
\hline I.R. & 0.70 & 0.15 & 0.43 & 0.00 \\
\hline $\mathrm{SiO}_{2}$ & 19.18 & 21.70 & 22.10 & 21.65 \\
\hline $\mathrm{Al}_{2} \mathrm{O}_{3}$ & 6.44 & 1.52 & 1.98 & 14.38 \\
\hline $\mathrm{Fe}_{2} \mathrm{O}_{3}$ & 1.75 & 4.11 & 4.46 & 0.53 \\
\hline $\mathrm{CaO}$ & 63.94 & 67.97 & 65.59 & 36.51 \\
\hline $\mathrm{MgO}$ & 1.48 & 0.42 & 0.83 & 2.36 \\
\hline $\mathrm{Na}_{2} \mathrm{O}$ & 0.90 & 0.43 & 0.15 & 0.05 \\
\hline $\mathrm{K}_{2} \mathrm{O}$ & 0.52 & 0.20 & 0.05 & 0.39 \\
\hline $\mathrm{TiO}_{2}$ & - & - & - & 0.27 \\
\hline $\mathrm{P}_{2} \mathrm{O}_{5}$ & - & - & - & 0.23 \\
\hline $\mathrm{SO}_{3}$ & 3.50 & 2.34 & 2.78 & 0.28 \\
\hline Total & 100.01 & 99.50 & 100.01 & 99.36 \\
\hline $\mathrm{H}_{2} \mathrm{O}\left(105^{\circ} \mathrm{C}\right)$ & 0.24 & 0.22 & 0.22 & 0.00 \\
\hline Free $\mathrm{CaO}$ & 1.9 & 1.75 & 1.20 & - \\
\hline $\mathrm{SiO}_{2}^{r-}$ & - & - & - & 16.17 \\
\hline $\mathrm{Al}_{2} \mathrm{O}_{3}^{r-}$ & - & - & - & 9.67 \\
\hline $\begin{array}{l}\text { Blaine specific surface } \\
\text { (BSS) }\left(\mathrm{m}^{2} / \mathrm{kg}\right)\end{array}$ & 319 & 329 & 323 & 350 \\
\hline Specific gravity $\left(\mathrm{g} / \mathrm{cm}^{3}\right)$ & 3.08 & 3.21 & 3.16 & 2.63 \\
\hline $\mathrm{C}_{3} \mathrm{~S}$ & 51.05 & 79.43 & 58.19 & - \\
\hline $\mathrm{C}_{2} \mathrm{~S}$ & 16.48 & 2.29 & 19.46 & - \\
\hline $\mathrm{C}_{3} \mathrm{~A}$ & 14.11 & 0.00 & 0.00 & - \\
\hline $\mathrm{C}_{4} \mathrm{AF}$ & 5.33 & 10.19 & 11.75 & - \\
\hline
\end{tabular}

3. Very pure ground natural gypsum stone, $\mathrm{CaSO}_{4} \cdot 2 \mathrm{H}_{2} \mathrm{O}$ (Tables 2 and 3). The chemical analysis was determined by $\mathrm{X}$-ray fluorescence (XRF).

All the blended cements were first tested for pozzolanicity using the Frattini method [EN 196-5 Standard (AENOR 2005)] (Table 4), which determines the amount of $\mathrm{Ca}(\mathrm{OH})_{2}$ originating from the PC hydration taking place in an aqueous solution containing the hydrated sample at time $t(=20,60,120$, and $480 \mathrm{~min}$ and 1, 2, 7, and 28 days in this study). The values found are then plotted on the

Table 2. Chemical Characteristics of Gypsum

\begin{tabular}{|c|c|}
\hline Chemical parameter & $\%$ in mass \\
\hline $\mathrm{H}_{2} \mathrm{O}\left(40-217^{\circ} \mathrm{C}\right)$ & 20.13 \\
\hline $\mathrm{CO}_{2}\left(217-1,000^{\circ} \mathrm{C}\right)$ & 0.75 \\
\hline Insoluble residue & 0.26 \\
\hline $\mathrm{SiO}_{2}$ & 0.04 \\
\hline $\mathrm{SO}_{3}$ & 45.87 \\
\hline $\mathrm{CaO}$ & 32.54 \\
\hline $\mathrm{MgO}$ & 0.36 \\
\hline $\mathrm{Na}_{2} \mathrm{O}$ & 0.02 \\
\hline $\mathrm{K}_{2} \mathrm{O}$ & 0.01 \\
\hline Total & 99.98 \\
\hline
\end{tabular}

Table 3. Mineralogical Composition of Gypsum

\begin{tabular}{lc}
\hline Mineralogical composition & in mass \\
\hline $\mathrm{CaSO}_{4} \cdot 2 \mathrm{H}_{2} \mathrm{O}$ & 95.58 \\
$\mathrm{CaSO}_{4} \cdot 1 / 2 \mathrm{H}_{2} \mathrm{O}$ or $\mathrm{CaSO}_{4}$ & 2.47 \\
$\mathrm{CaCO}_{3}$ & 0.75 \\
$\mathrm{MgCO}$ & 0.81 \\
Total & 99.61 \\
\hline
\end{tabular}

same graph as the calcium hydroxide $\left[\mathrm{Ca}(\mathrm{OH})_{2}\right]$ solubility isotherm curve estimated for an alkaline solution at $40^{\circ} \mathrm{C}$. Any $\mathrm{CaO}$ and $\mathrm{OH}^{-}$points underneath that curve are indicative of pozzolanic activity. The PC/MC replacement ratios used in this test [EN 196-5 Standard (AENOR 2005)] were $80 / 20$ and $60 / 40 \%$ by weight.

Lastly, each blended cement $(80 / 20,70 / 30$, and 60/40) (P1/ $\mathrm{MC}$ and $\mathrm{P} 2 / \mathrm{MC})$ and each $\mathrm{PC}(\mathrm{P} 1, \mathrm{P} 2$, and $\mathrm{P} 3)$ were submitted to the L-A test (Blondiau 1961; Talero 2002). In it, the cement is firstly ground to pass a sieve with an approximately 88-mm opening (a no. 170 sieve) and the grounded cement, $100.0 \mathrm{~g}$, are made into a 0.50 water/cement ratio paste allowed to harden for several weeks (commonly 14 days) and then crushed to 5-mm size and dried at over $40^{\circ} \mathrm{C}$. Natural gypsum stone $(50.0 \mathrm{~g}$ as $150 \%$ of the dried set cement) is added, and the mixture is ground to pass a sieve with an approximately 212-mm opening (a no. 70 sieve) to accelerate internal sulfate attack (like the ASTM C452 test as well, which is 60 years old giving reliability, safety, and usefulness, however). Six percent of distilled water by weight of solids is added, and the dampened paste is placed in a cylindrical mold, $80 \times$ $30 \mathrm{~mm}$ high, and compressed under a pressure of $196 \mathrm{~Pa} / \mathrm{min}$. Each specimen $\left(\varnothing_{0}=80 \mathrm{~mm}\right)$ was kept at $100 \% \mathrm{RH}$ in separate airtight bell jars over a film of distilled water. The temperature in these jars was held at $21 \pm 2{ }^{\circ} \mathrm{C}$. The diameter was measured periodically, at times varying from 1 to 1,200 days depending on the purpose. The $\Delta \varnothing(\%)$ values were compared to the maximum allowable 28-day expansion, defined as $1.25 \%$ (physical requirement) (Talero 1986, 1989, 2002), and used to determine the diameter growth rate, $V c \varnothing[=\Delta \emptyset(\%) /$ day $]$, which was calculated by dividing the measured increase in diameter, $\Delta \emptyset(\%)$, by the number of days lapsing since the preceding measurement. Vicat needle penetration (VNP) measurements were also taken to gather information on specimen expansion and spalling.

Furthermore, P2 (an additional L-A specimen was prepared for comparison with the P3 L-A specimen for reasons explained later) and P3 L-A specimens were kept in separate airtight bell jars over a film of distilled water in moist cabinet at $100 \% \mathrm{RH}$ and $15 \pm 1^{\circ} \mathrm{C}$. The lids were immediately closed after the $\varnothing, h$, and VNP measurements were taken at the ages specified throughout the 18-year trial period.

Lastly, part of the L-A specimens were collected, dried at in $\mathrm{a} \mathrm{CO}_{2}$-free atmosphere, and ground to the particle size of the original cement. These samples were analyzed on a Philips PW 1730 $\mathrm{X}$-ray powder diffractor (XRD) fitted with a graphite monochromator (power settings of $40 \mathrm{kV}$ and $20 \mathrm{~mA}$ ) and set for $\mathrm{CuK} 1=1.54056$ and $\mathrm{CuK} 2=1.54439$ radiation, $(\mathrm{K} 1 / \mathrm{K} 2)=0.50$. The scanning rate was $0.02^{\circ} \mathrm{C}$ and the step time $0.80 \mathrm{~s}$ in a range of $5-30^{\circ} \mathrm{C}$.

\section{Results and Discussion}

The chemical analysis of the MC used (Table 1) revealed that its loss on ignition (at $950 \pm 25^{\circ} \mathrm{C}$ ) was a fairly high $23.21 \%$, a value attributed, in descending order of likelihood, to:

- Incineration of its organic matter, primarily cellulose fibers;

- Dehydroxylation of its initial kaolinite fraction, in the wake of the optimized dehydroxylation (Frías et al. 2008a), after the organic matter was consumed; and

- Possible partial decarboxylation of its initial calcite fraction (at temperatures of $600-700^{\circ} \mathrm{C}$ ).

Chemical analysis also confirmed the high $\mathrm{Al}_{2} \mathrm{O}_{3}^{r-}(\%)$ content in this MC waste, 9.67\% (Table 1). As discussed later, its Le Chatelier-Anstett test behavior was not in keeping with its significant $\mathrm{SiO}_{2}^{r-}$ content, $16.17 \%$ (Table 1) (Talero and Rahhal 2009; Talero 1986, 2002, 2011c). 
Table 4. Frattini Test Results for P1, P2 Blended Cements with MC

\begin{tabular}{|c|c|c|c|c|c|c|c|c|c|c|c|c|}
\hline \multirow[b]{2}{*}{ Age } & \multicolumn{2}{|c|}{$\mathrm{P} 1(\mathrm{mM} / \mathrm{l})$} & \multicolumn{2}{|c|}{$\begin{array}{l}\mathrm{P} 1 / \mathrm{MC} 80 / 20 \\
(\mathrm{mM} / \mathrm{l})\end{array}$} & \multicolumn{2}{|c|}{$\begin{array}{l}\mathrm{P} 1 / \mathrm{MC} 60 / 40 \\
(\mathrm{mM} / \mathrm{l})\end{array}$} & \multicolumn{2}{|c|}{$\mathrm{P} 2(\mathrm{mM} / \mathrm{l})$} & \multicolumn{2}{|c|}{$\begin{array}{l}\text { P2 } \underset{(\mathrm{mM} / \mathrm{l})}{\mathrm{M} / 20 / 20} \\
\end{array}$} & \multicolumn{2}{|c|}{$\begin{array}{l}\mathrm{P} 2 \underset{(\mathrm{mM} / \mathrm{l})}{\mathrm{MC} 60 / 40} \\
\end{array}$} \\
\hline & {$\left[\mathrm{OH}^{-}\right]$} & {$[\mathrm{CaO}]$} & {$\left[\mathrm{OH}^{-}\right]$} & {$\left[\mathrm{OH}^{-}\right]$} & {$[\mathrm{CaO}]$} & {$\left[\mathrm{OH}^{-}\right]$} & {$[\mathrm{CaO}]$} & {$\left[\mathrm{OH}^{-}\right]$} & {$[\mathrm{CaO}]$} & {$[\mathrm{CaO}]$} & {$\left[\mathrm{OH}^{-}\right]$} & {$[\mathrm{CaO}]$} \\
\hline $20 \mathrm{~min}$ & 40.00 & 39.50 & 25.16 & 38.25 & 25.33 & 34.45 & 24.50 & 49.18 & 33.25 & 38.92 & 36.14 & 37.98 \\
\hline $60 \mathrm{~min}$ & 42.50 & 34.68 & 32.01 & 38.86 & 31.10 & 34.19 & 29.50 & 43.35 & 39.44 & 34.01 & 39.27 & 36.68 \\
\hline $120 \mathrm{~min}$ & 42.75 & 31.90 & 40.26 & 35.42 & 31.93 & 34.42 & 31.50 & 41.10 & 40.00 & 33.55 & 37.70 & 20.63 \\
\hline $480 \mathrm{~min}$ & 50.00 & 16.00 & 44.88 & 25.92 & $37.62^{\mathrm{a}}$ & $16.33^{\mathrm{a}}$ & 39.50 & 32.00 & 38.80 & 25.00 & 35.00 & 16.00 \\
\hline 1 day & 66.50 & 8.73 & 55.44 & 8.30 & 47.34 & 8.37 & 42.75 & 28.33 & 38.61 & 20.33 & 33.99 & 14.34 \\
\hline 2 days & 72.50 & 7.60 & 56.10 & 7.41 & 49.67 & 7.14 & 42.50 & 21.50 & 37.79 & 15.91 & 28.71 & 13.79 \\
\hline 7 days & 71.25 & 6.80 & 83.16 & 4.14 & 60.46 & 6.36 & 39.45 & 16.55 & 38.28 & 14.75 & 33.99 & 14.34 \\
\hline 28 days & 78.00 & 6.45 & 83.49 & 3.74 & 61.05 & 6.07 & 42.00 & 16.10 & 36.14 & 13.20 & 31.35 & 12.82 \\
\hline
\end{tabular}

${ }^{\text {a }}$ This P1/MC 60/40 blend almost met the Frattini test requirement at this very early age; the paired values in bold mean that the point is in the subsaturation region $(=+$ result $)$.

\section{Frattini Test Results}

The pozzolanic activity results for the PC/MC blends are shown in Table 4. The MC exhibited high reactivity with both PCs as early as 1 day into the experiment, and even earlier than its 60/40 P2/MC blend, due to its high $\mathrm{SiO}_{2}^{r-}(16.17 \%)$ and $\mathrm{Al}_{2} \mathrm{O}_{3}^{r-}(9.67 \%)$ contents. The respective pozzolanicities, particularly for the P1 blends, were much higher and appeared earlier in the blends than in the unblended PC (with which pozzolanicity never appeared as logical), which consumed more $\mathrm{Ca}^{2+}$ than $\mathrm{OH}^{-}$ions. Moreover, pozzolanic activity grew with the $\mathrm{PC}$ replacement ratio in both blended cements. While such high and early MC-induced pozzolanic activity was clearly observed in both the P1 and P2 blends, the patterns subsequently followed through the end of the trial varied considerably. This might be attributed to the following:

1. One cause might be the difference in their $\mathrm{Na}_{2}$ Oeq. contents (1.24 and $0.56 \%$, respectively higher and lower than $0.60 \%$ (Talero 1989), in turn the outcome of their widely dissimilar $\mathrm{C}_{3} \mathrm{~A}$ content (14.11 and $0.00 \%$, respectively), whereby the $60 / 40 \mathrm{P} 2 / \mathrm{MC}$ passed theFrattini test after just $480 \mathrm{~min}$, while the $60 / 40 \mathrm{P} 1 / \mathrm{MC}$ did not.

2. A second would be the very dissimilar behavior of the MC waste when blended with each PC:

- the [CaO] in 80/20 P1/MC rose between 20 and 60 min and remained more or less flat from 20 to $120 \mathrm{~min}$ in 60/40 P1/ $\mathrm{MC}$, because direct (the result of MC particle moistening by the mixing water from the outset) (Rahhal and Talero 2005) and nondirect (due to the positive and negative electrostatic charge acquired by the particles of calcite especially during grinding and subsequently, to the zeta potential generated as PC hydration progresses, i.e., to the role of the calcite filler particles and especially of the metakaolin particles as precipitation and nucleation centres for calcium hydroxide crystals) (Rahhal et al. 2012) stimulation of PC P1 hydration prevailed over indirect stimulation (due to the high, early, and fast pozzolanic activity developed by the $\mathrm{Al}_{2} \mathrm{O}_{3}^{r-}$ content of the metakaolin fraction present in MC waste) (Talero and Rahhal 2009; Talero 2011a, c); after those ages, this third type of stimulation predominated through the end of the Frattini test, while

- the $\mathrm{CaO}$ in 80/20 and 60/40 P2/MC decreased after 20 min because hydrationwas stimulated indirectly throughout.

$\mathrm{C}_{3} \mathrm{~A}$, the most active phase in $\mathrm{P} 1$, was further activated by the $\mathrm{MC}$, especially at early ages, inducing competition between the two sulfate- and nonsulfate-mediated hydration reactions (Talero 1986, 2002, 2005, 2007, 2009, 2010, 2011a, c; Rahhal and Talero 2014). Conversely, MC action in the P2 blends was limited only by the amount of $\mathrm{C}_{3} \mathrm{~S}$ present. Although this was the majority constituent in this PC, its hydration took place more slowly and, obviously, with no interaction with $\mathrm{C}_{3} \mathrm{~A}$. Therefore, $\mathrm{MC}$ exhibited lower pozzolanicity in $\mathrm{P} 2$ (with $0.00 \% \mathrm{C}_{3} \mathrm{~A}$ ) than in the PC P1 blends (with 11.2 and $8.47 \% \mathrm{C}_{3} \mathrm{~A}$, for $80 / 20$ and $60 / 40$ blends, respectively), whose $\mathrm{Ca}^{2+}$ ion uptake was substantial as early as $480 \mathrm{~min}$. Direct and nondirect stimulation of the hydration reactions prevailed in these systems (Table 4). In the $0.00 \% \mathrm{C}_{3} \mathrm{~A}$ P2 blends, however, early and significant pozzolanic activity prevailed only from the beginning of the Frattini test, for which reason even the 480-min $60 / 40$ P2/MC met the test requirement (Table 4).

The results were promising in both cases, particularly at the higher PC replacement ratio. The $\mathrm{CaO}$ and $\mathrm{OH}^{-}$differed: in the two blends P1/MC exhibited fairly steady calcium hydroxide uptake which coexisted noncompetitively in the liquid phase with the $\mathrm{Na}_{2}$ Oeqresulting from $\mathrm{P} 1$ hydration. In contrast, in $\mathrm{P} 2 / \mathrm{MC}$ the $\mathrm{Al}_{2} \mathrm{O}_{3}^{r-}(\%)$ content in the $\mathrm{MC}$ tended to keep the $\mathrm{OH}^{-}$content and react with $\mathrm{Ca}^{2+}$, giving rise to Stratling's compound, a calcium aluminate hydrate (Murat 1983a, b, Murat and Comel 1983), and where gypsum was present calcium aluminate hydrates, ett-rf, and AFm phase (Talero 2002, 2005, 2007, 2009, 2010, 2011a, c).

\section{Le Chatelier-Anstett (L-A) Test Results}

The L-A test findings (Figs. 1-4) showed that, further to the criteria put forward by Talero 1986, 1989, 2002) [high sulfate resistance $(\mathrm{SR})=\Delta \emptyset_{28 \text { days }} \leq 1.25 \%$; moderate $\mathrm{SR}=1.25 \%<\Delta \emptyset_{28 \text { days }}<$ $4.00 \%$; low $\mathrm{SR}=\Delta \varnothing_{28 \text { days }} \geq 4.00 \%$ ], P2 was highly sulfate resistant, for its $0.75 \% \Delta \emptyset_{28 d}$ was lower than the $1.25 \%$ ceiling [Fig. 1(b)] (P3 also met this physical requirement [Fig. 4(a)]. This result was consistent with the crystalline composition of this PC (RC-75 1975, RC-08 2008), according to which its $\mathrm{C}_{3} \mathrm{~A}$ content was $0.00 \%$, and its $\mathrm{C}_{4} \mathrm{AF}$ content was $10.19 \%$ wt., (Table 1). On the contrary, none of the P2/MC blends could be classified as even moderately sulfate-resistant cements (Talero 1986, 2002, 2005, 2007, 2009, 2010, 2011a, c; Rahhal and Talero 2014), for the $\Delta \emptyset_{28 d}$ found for their L-A specimens lay above the established $1.25 \%$ at $4.00 \%$ range [Figs. 1(b) and 4]. Nor did P1 qualify for this category, for the L-A test findings confirmed that at $14.11 \%$ its $\mathrm{C}_{3} \mathrm{~A}$ content was significantly higher than the $5 \%$ ceiling defined for sulfate-resistant cement [RC-75 (Ministerio de Obras Poblicas 1975); RC-08 (Ministerio de Fomento 2008); EN 197-1 (AENOR 2011); ASTM C 150-14 (ASTM 2014)]. Similar or less favorable behavior was observed for the blended cements prepared with P1 [Figs. 1(a), 2(a), and 3(a)].

By way of summary, all the cements tested, except P2 and P3, resisted gypsum attack poorly. Worse, however, was that the same behavior was recorded for all the $\mathrm{P} 1 / \mathrm{MC}$, whose sulfate resistance declined with rising proportion of $\mathrm{MC}$ and higher $\mathrm{C}_{3} \mathrm{~A}$ content in 

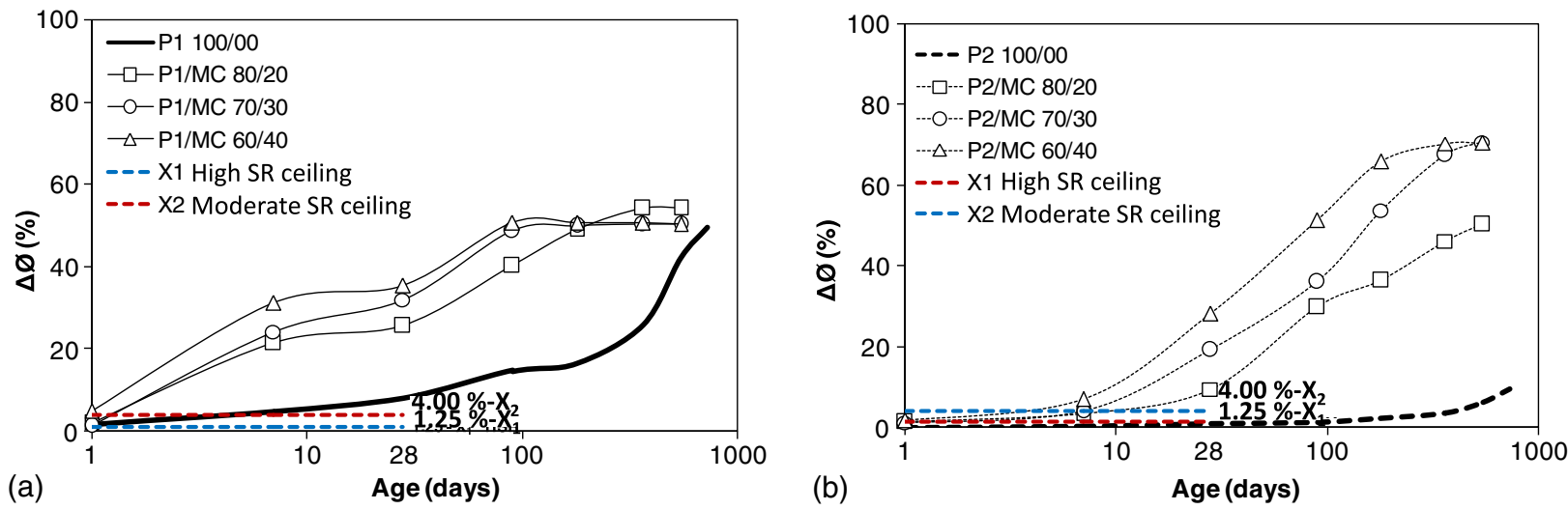

Fig. 1. L-A specimens: increase in diameter, $\Delta \varnothing(\%)$, versus time in PC, (a) P1 and (b) P2, and their MC-bearing POZCs
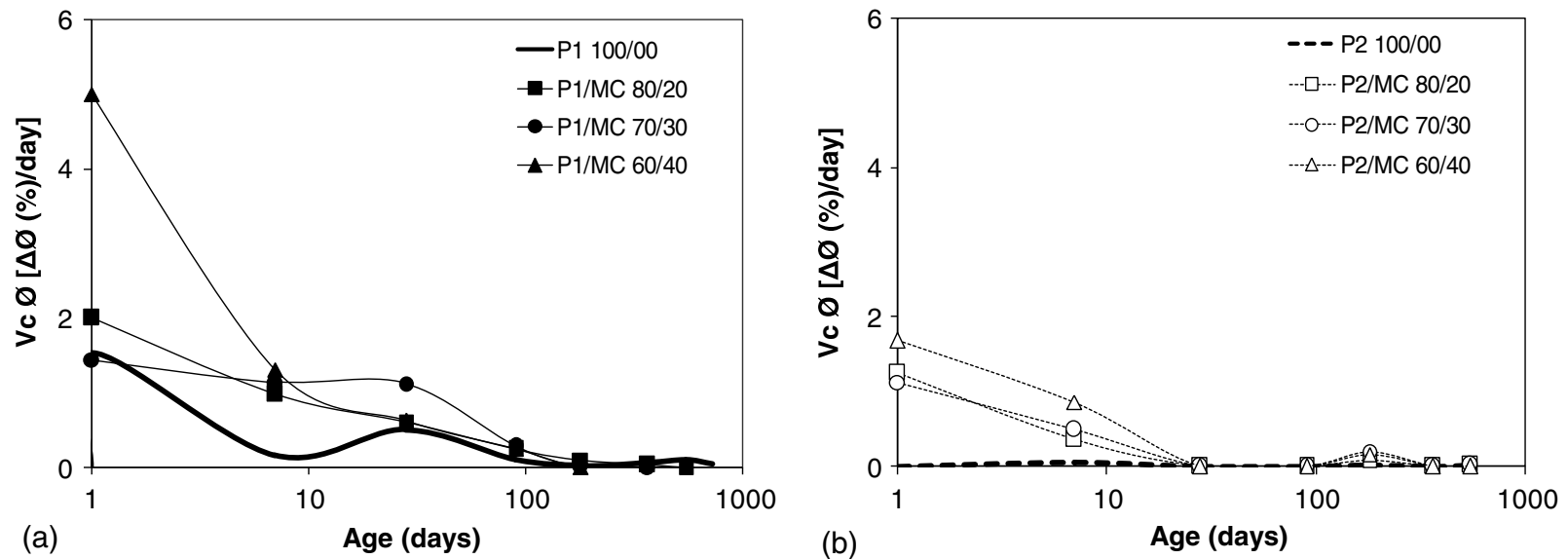

Fig. 2. L-A specimens: diameter growth rate, $V_{C \varnothing}$ versus time in PC, (a) P1 and (b) P2, and their MC-bearing POZCs
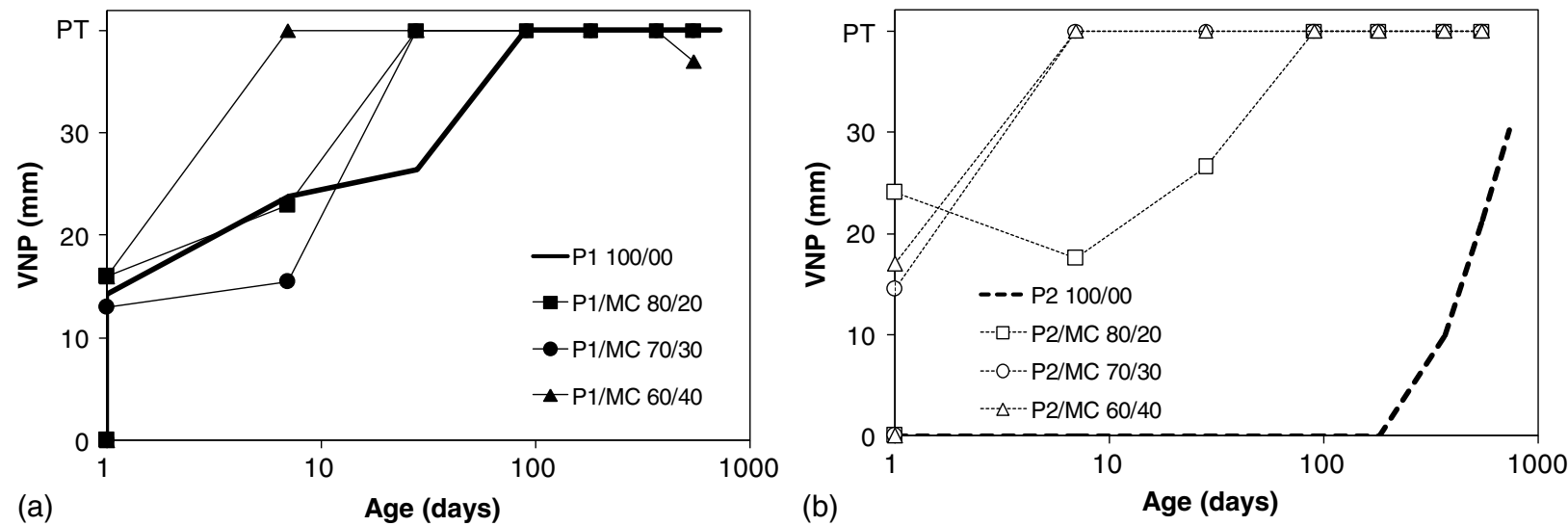

Fig. 3. L-A specimens: Vicat needle penetration (VNP) (mm) versus time in PC, (a) P1 and (b) P2, and their MC-bearing POZCs

their PC (Talero 1986, 2002, 2005, 2007, 2009, 2010, 2011a, c; Rahhal and Talero 2014). Note that even initially in P2, sulfate resistance fell as the proportion of $\mathrm{MC}$ in the blends rose. The gypsum attack affected P1 blended cements more quickly than P1 [rapid gypsum attack (Talero 1986, 2002, 2005, 2007, 2009, 2010, 2011a, c; Rahhal and Talero 2014)].

None of the P1/MC and P2/MC blended cements could, then, be regarded as sulfate-resistant [Figs. 1-3(a and b)].
The foregoing was corroborated by the VNP findings [Figs. 3(a and b) and 4(c)], which detected a soft pulpy mass attributed to the direct sulfate attack on the $\mathrm{C}_{3} \mathrm{~A}$ [Figs. 3(a) and 4(c)], the C-S-H gel, or both. This finding was a sign of C-S-H gel replacement by thaumasite, the source of whose carbonate ions was $\mathrm{MC}$, portlandite carbonation, or both [Figs. 3(b) and especially 4(c)]. The P2 and P3 $\mathrm{L}-\mathrm{A}$ specimens were stored in a moist cabinet at $15 \pm 1{ }^{\circ} \mathrm{C}$. The general chemical reaction can be expressed as follows using the 

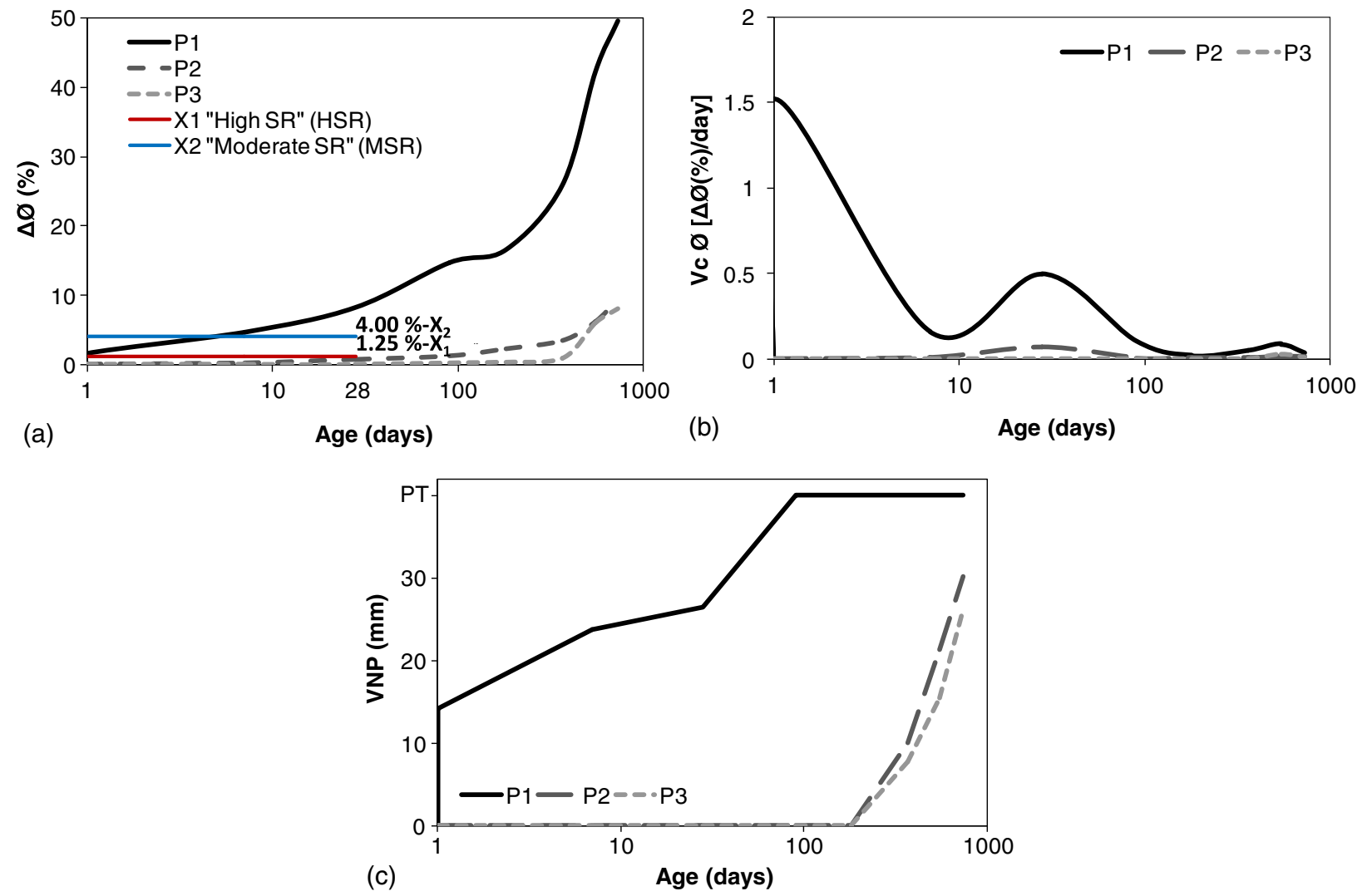

Fig. 4. L-A specimens: fluctuations versus time in (a) diameter, $\Delta \varnothing(\%)$; (b) $V_{C \varnothing}$; (c) Vicat needle penetration (VNP) (mm) in PC P1, P2, and P3

approximate formula $\mathrm{Ca}_{3} \mathrm{Si}_{2} \mathrm{O}_{7} \cdot 3 \mathrm{H}_{2} \mathrm{O}$ for the nonstoichiometric calcium silicate hydrate C-S-H (Bensted 1999):

$$
\begin{aligned}
& \mathrm{Ca}(\mathrm{OH})_{2}+\mathrm{CO}_{2} \rightarrow \mathrm{CaCO}_{3}+\mathrm{H}_{2} \mathrm{O} / \mathrm{CaCO}_{3} \\
& \left(\mathrm{MC}_{\text {origin }} \text { and/or portlanditecarbonation } \text { origin }_{1}\right)
\end{aligned}
$$

$$
\begin{gathered}
\mathrm{Ca}_{3} \mathrm{Si}_{2} \mathrm{O}_{7} \cdot 3 \mathrm{H}_{2} \mathrm{O}+2\left\{\mathrm{CaSO}_{4} \cdot 2 \mathrm{H}_{2} \mathrm{O}\right\}+\mathrm{CaCO}_{3}+24 \mathrm{H}_{2} \mathrm{O} \\
\rightarrow \mathrm{Ca}_{6}\left[\mathrm{Si}(\mathrm{OH})_{6}\right]_{2}\left(\mathrm{CO}_{3}\right)_{2}\left(\mathrm{SO}_{4}\right)_{2} \cdot 24 \mathrm{H}_{2} \mathrm{O}+\mathrm{Ca}(\mathrm{OH})_{2}
\end{gathered}
$$

$$
\begin{gathered}
\mathrm{Ca}_{3} \mathrm{Si}_{2} \mathrm{O}_{7} \cdot 3 \mathrm{H}_{2} \mathrm{O}+2\left\{\mathrm{CaSO}_{4} \cdot 2 \mathrm{H}_{2} \mathrm{O}\right\}+\mathrm{CaCO}_{3}+\mathrm{CO}_{2} \\
+23 \mathrm{H}_{2} \mathrm{O} \rightarrow \mathrm{Ca}_{6}\left[\mathrm{Si}(\mathrm{OH})_{6}\right]_{2}\left(\mathrm{CO}_{3}\right)_{2}\left(\mathrm{SO}_{4}\right)_{2} \cdot 24 \mathrm{H}_{2} \mathrm{O}
\end{gathered}
$$

The explanation of the aforementioned results is that in an aqueous calcium hydroxide medium MC waste has been shown to give rise to new hydration products such as: $\mathrm{C}-\mathrm{S}-\mathrm{H}$ gels (II) with a $\mathrm{Ca} / \mathrm{Si}$ ratio of $2-1.5$, laminar tobermorite with $\mathrm{Ca} / \mathrm{Si}$ approximately 0.8 , and a thompsonite zeolite $\left[\mathrm{Na}_{4} \mathrm{Ca}_{8}\left(\mathrm{Al}_{2} \mathrm{OSi}_{20} \mathrm{O}_{80}\right) \cdot 24 \mathrm{H}_{2} \mathrm{O}\right]$ (Frías et al. 2008a, b; García et al. 2008, 2010; Rodríguez et al. 2008). In this new study, due to the 14-day pre-sulfate attack hydration to which the cementitous materials had to be exposed, other chemical compounds were observed to form: $\mathrm{C}_{4} \mathrm{AH}_{13}, \mathrm{C}_{4} \mathrm{AH}_{x}$, $\mathrm{C}_{4} \mathrm{AH}_{13}\left(\mathrm{CO}_{2}\right), \mathrm{C}_{4} \mathrm{AH}_{11}\left(\mathrm{CO}_{2}\right)$. The post-sulfate attack products were rapid-forming ettringite (ett-rf) (Talero 1986, 2002, 2005, 2007, 2009, 2010, 2011a, c; Rahhal and Talero 2014) and finally thaumasite.

The C-S-H gels precipitating from the reactive silica $\left(\mathrm{SiO}_{2}^{r-}\right)$ component of the metakaolin in the $\mathrm{MC}$ used, like the $\mathrm{C}-\mathrm{S}-\mathrm{H}$ gels forming from the $\mathrm{C}_{3} \mathrm{~S}$ in $\mathrm{P} 2$, would be difficult to identify with $\mathrm{XRD}$. The presence of anhydrous fractions such as $\mathrm{C}_{3} \mathrm{~S}, \mathrm{C}_{2} \mathrm{~S}$ and $\mathrm{C}_{4} \mathrm{AF}$ would be readily detected, however, as in previous studies
(Talero 1986, 2002, 2005, 2007, 2009, 2010, 2011a, c; Rahhal and Talero 2014; Rahhal et al. 2010).

Lastly, the parameters providing the greatest insight into the cause of PC/MC blend behavior when exposed to sulfate attack were the diameter growth rate $\left(V_{C \varnothing}\right.$ versus time), the increase in L-A specimen diameter $[\Delta \emptyset(\%)$ versus time], and, graphed respectively in Figs. 1 and 2, questions regarding parameter $V c \varnothing$ versus time (Fig. 2):

1. Why was the absolute value of the negative slope for specimen 60/40 P1/MC [Fig. 2(a)] always greater than for specimen 60/ $40 \mathrm{P} 2 / \mathrm{MC}$ [Fig. 2(b)], given that both specimens had the same MC content (40\%)? More specifically: why was the $V c \emptyset_{1 \text { day }}$ for specimen $60 / 40 \mathrm{P} 1 / \mathrm{MC} 1.8$ times greater than the theoretical $V c \emptyset_{1 \text { day }}$ ? Why was the $V c \emptyset_{1 \text { day }}$ for specimen $60 / 40 \mathrm{P} 1 / \mathrm{MC}$ over twice as high as for specimen $60 / 40 \mathrm{P} 2 / \mathrm{MC}$ and nearly three times the value for the pure P1 specimen?

2. What might be the cause of such a large difference in behavior in pastes containing the same amount of $\mathrm{MC}(40 \%)$ and under the same conditions? In other words, what distinguishes L-A specimen 60/40 P1/MC from specimen 60/40 P2/MC?

The sole reply to all those questions could hardly be more conclusive: The behavior of the two L-A specimens differs because their $\mathrm{C}_{3} \mathrm{~A}$ content differs as well.

While both pastes contained $26.4 \%$ calcite plus metakaolin with a $3.9 \% \mathrm{Al}_{2} \mathrm{O}_{3}^{r-}$ content, both present in the MC waste, only $\mathrm{P} 1$ had $\mathrm{C}_{3} \mathrm{~A}(8.47 \%=60 \times 14.11 \%)$. Consequently, the substantial difference observed between the $V c \varnothing$ values for the two L-A specimens must be attributed solely to the aforementioned $8.47 \%$ difference in their respective $\mathrm{C}_{3} \mathrm{~A}$ contents:

- If that had been all the $\mathrm{C}_{3} \mathrm{~A}$ in the $\mathrm{P} 1 / \mathrm{MC} \mathrm{L}-\mathrm{A}$ specimen or MC waste had been completely inert from the point of view of sulfate resistance, it would have generated a $V c \varnothing$ curve similar to 


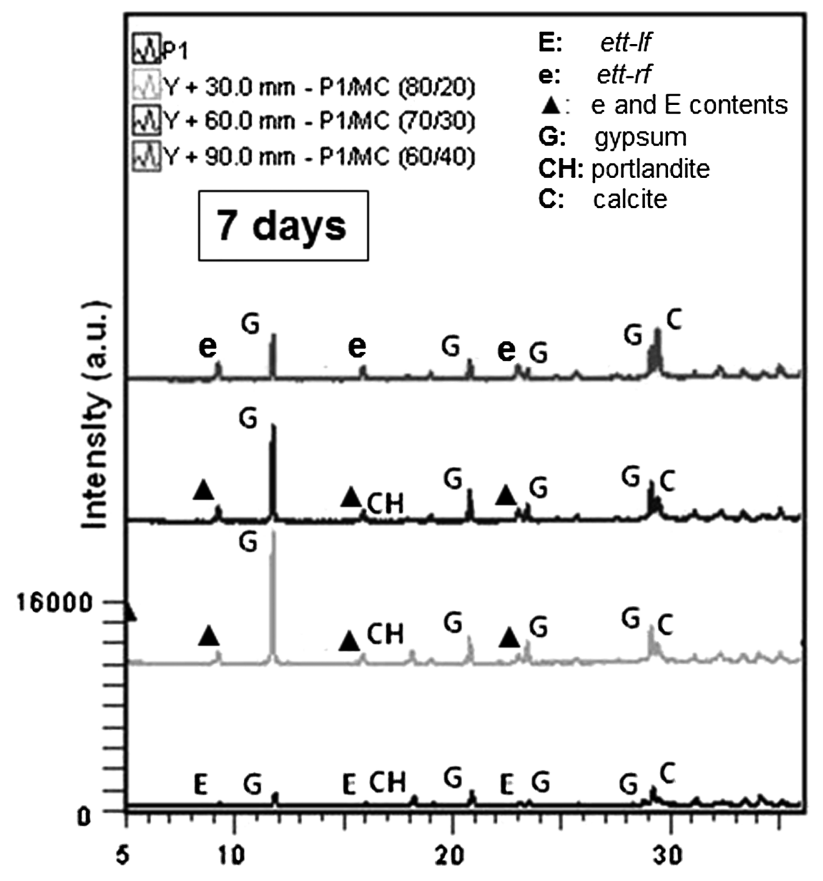

(a)

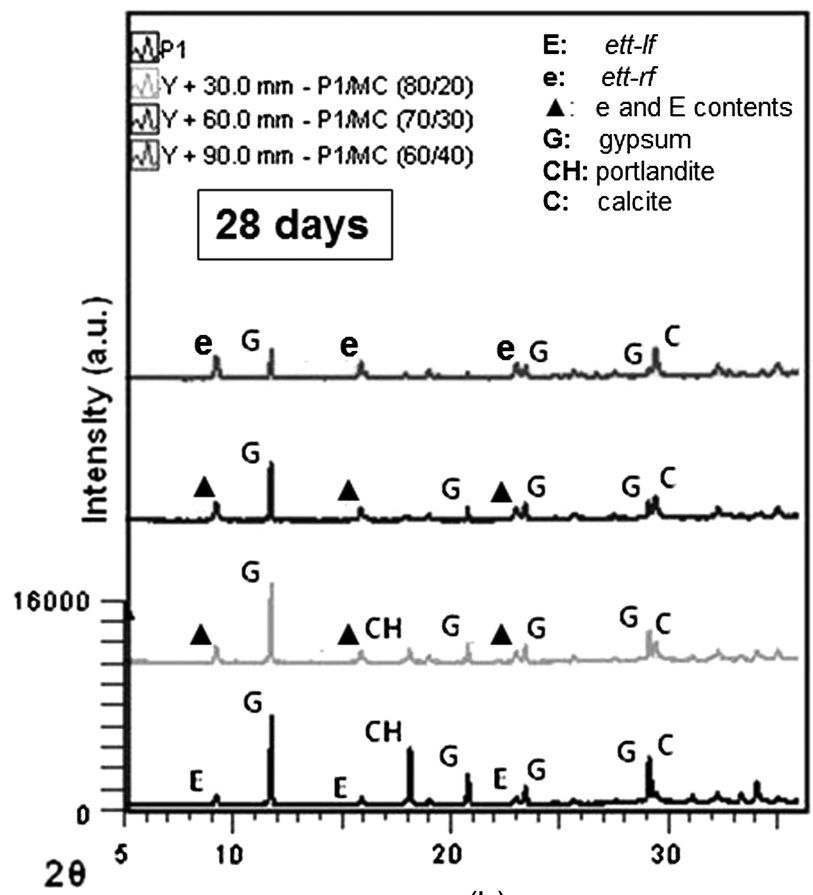

(b)

Fig. 5. XRD patterns for OPC P1 and its (a) 7- and (b) 28-day MC-bearing POZC; temperature: $21 \pm 2{ }^{\circ} \mathrm{C}$ (see additionally abbreviations section)

the one generated by pure P1, except that the $V c \varnothing$ values would have been $40 \%$ lower and induced by ett-lf only, E in Fig. 5 [as experimentally proven in prior studies (Talero 2002, 2005, 2007, 2009, 2010, 2011a, c; Rahhal and Talero 2014; Rahhal et al. 2010)]. That was not the case, however, in $60 / 40 \mathrm{P} 1 / \mathrm{MC}$, in which the $\mathrm{MC}$ (40\% of the blend) contributed $3.9 \% \quad \mathrm{Al}_{2} \mathrm{O}_{3}^{r-}$ (and also contained $26.4 \%$ calcite), yielding an actual $V c \emptyset_{1 \text { day }}$ value 1.8 times greater than the theoretical value. Moreover, the absolute value of the negative slope on the $V c \varnothing$ curve from early ages was substantially greater than for the pure P1 L-A specimen and especially for the 60/40 P2/MC specimen [as also experimentally proven previously for metakaolin of a different origin (Talero 2007, 2010, 2011a, c)]: It must, then, have been the result of ett-rf only (e in Fig. 5), as once again proven experimentally for such metakaolin (Talero 2002, 2005, 2007, 2009, 2010, 2011c).

- Because the $40 \% \mathrm{MC}$ was the main source of reactive alumina $\left(\mathrm{Al}_{2} \mathrm{O}_{3}^{r-}\right)$ in the $60 / 40 \mathrm{P} 2 / \mathrm{MC} \mathrm{L}-\mathrm{A}$ specimen, its $V c \varnothing$ curve may have denoted the action of ett-rf only, which must have formed at a very early age [proven experimentally (Talero 2002, 2005, 2007, 2009, 2010, 2011c)]. When the MC was mixed with the $8.47 \% \mathrm{C}_{3} \mathrm{~A}$ in $\mathrm{P} 1$, the increase in diameter must have been even more clearly induced by ett-rf only than when the MC was the main source of reactive alumina $\left(\mathrm{Al}_{2} \mathrm{O}_{3}^{r-}\right)$. This is because the high and speedy pozzolanicity generated by its $3.9 \%$ $\mathrm{Al}_{2} \mathrm{O}_{3}^{r-}$ after or even before the end of the first day (480 min, Table 4) must have in turn induced faster indirect sulfatemediated hydration (Talero and Rahhal 2009; Talero 2011a, c, 2012), especially of the $8.47 \% \mathrm{C}_{3} \mathrm{~A}$ with which it was mixed. For that reason (Talero and Rahhal 2009; Talero 2011a, c, 2012), such pozzolanic activity must be regarded as being more specific than generic, because it was able to indirectly (here in conjunction with direct and nondirect stimulation of the $26.4 \%$ calcite) stimulate sulfate-mediated $\mathrm{C}_{3} \mathrm{~A}$ hydration (Talero and Rahhal 2009; Talero 2011a, c, 2012). It did not stimulate hydration of the $30.63 \% \mathrm{C}_{3} \mathrm{~S}$ in $60 / 40 \mathrm{P} 1 / \mathrm{MC}$, however, for when $\mathrm{MC}$ replaced $40 \%$ of $\mathrm{P} 2$, the source of the $47.66 \% \mathrm{C}_{3} \mathrm{~S}$ content, its hydration was not stimulated at such early ages, with or without sulfates.

Further verification of the preceding explanation for this behavior and its cause is given in the following:

1. Firstly, the $V c \varnothing$ curves for the two sets of sister $\mathrm{L}-\mathrm{A}$ specimens, 80/20 and 70/30 P1/MC and 80/20 and 70/30 P2/MC, followed different patterns. In the latter two the rate of increase in diameter at early ages would have been induced primarily by ett-rf (Fig. 6), for which reason in the early weeks of the trial in particular the pattern would have had to be (and was) largely parallel to the shape of the curve for their sister $60 / 40 \mathrm{~L}-\mathrm{A}$ specimen. In contrast, the curves for the former two would have had to denote the contrary behavior because they would have produced more or less ett-lf and less or more ett-rf, respectively (Fig. 5), as earlier studies with a different metakaolin have shown (Talero 2010). The 80/20 and 70/30 P1/MC specimens should not, then, have behaved like their sister 60/40 L - A specimen, but rather should have more or less followed the pattern of their own pure P1. This was in fact observed in $80 / 20$ but less so in 70/30 P1/MC, whose behavior did resemble the pattern established by its sister 60/40 L - A P1/MC specimen (Fig. 2). Again, the explanation must be sought firstly in the fact that the amount of specific pozzolanic activity generated from day 1 by the 20 and $30 \%$ MC was too small to indirectly stimulate full sulfate-mediated hydration of the 11.29 and $9.88 \% \mathrm{C}_{3} \mathrm{~A}$ contents present in the 80 and $70 \%$, respectively, $\mathrm{P} 1$ fraction with which it was blended (Fig. 5).

2. Secondly, on the false assumption that $\mathrm{Al}_{2} \mathrm{O}_{3}^{r-}$-mediated ettringite formation in the metakaolin was not of the rapid- but rather of the slow-forming variety, like the mineral deriving from the $\mathrm{C}_{3} \mathrm{~A}$ in $\mathrm{P} 1$, the $V c \varnothing$ curve for the $60 / 40 \mathrm{P} 1 / \mathrm{MC} \mathrm{L}-\mathrm{A}$ specimen would have necessarily had to be parallel to the curve for P1 itself [in which the increase in specimen diameter was due to ett-lf formation only (Fig. 5)]. It would also have had to lie underneath the P1 curve and had a less steep, sinusoid slope (as would the curves for the three $\mathrm{P} 2 / \mathrm{MC} \mathrm{L}-\mathrm{A}$ specimens, for the same reason). The curve was neither parallel to the $\mathrm{P} 1$ curve nor 

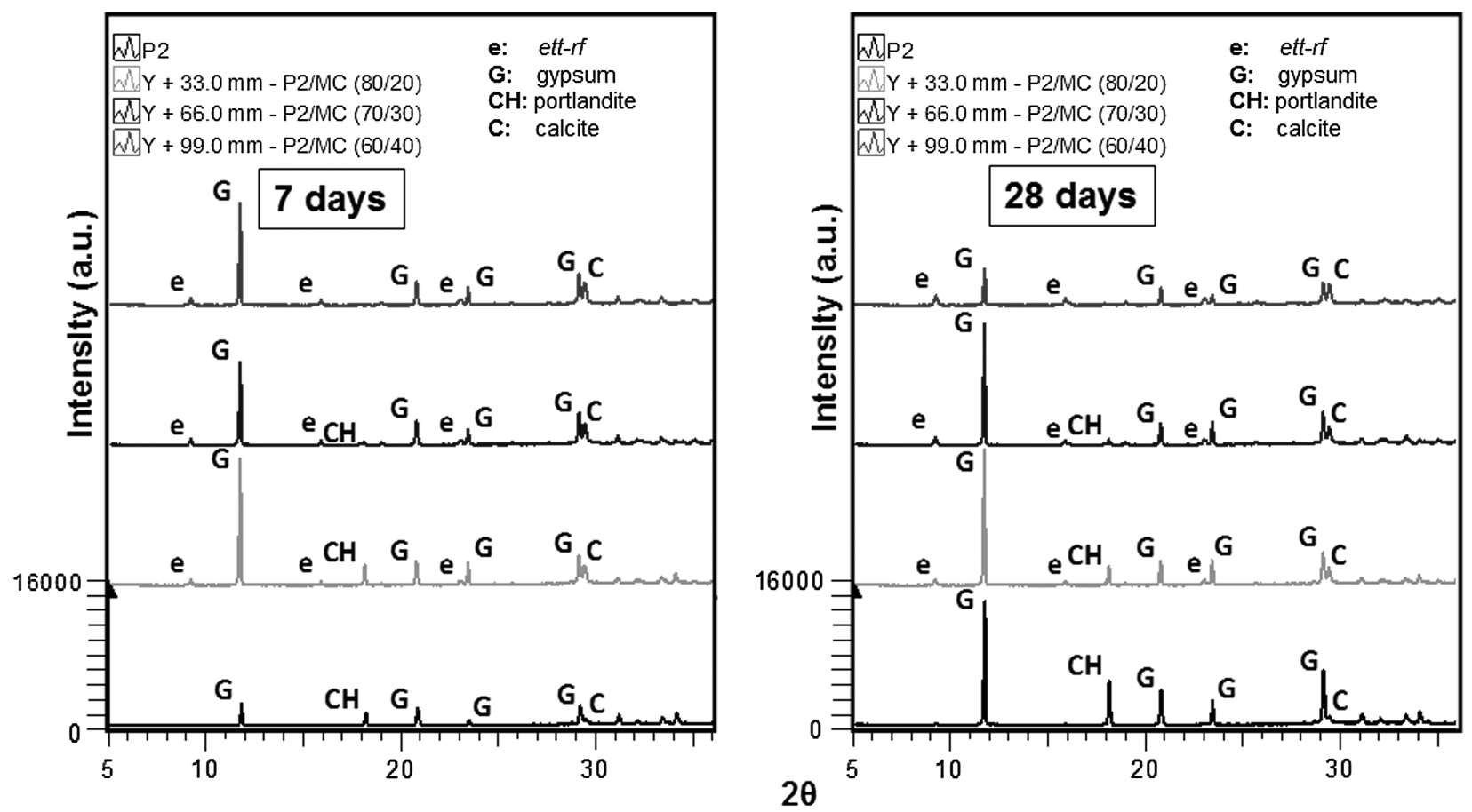

Fig. 6. XRD patterns for SRPC P2 and 7- and 28-day 60/40, 70/30, and 80/20 P2/MC; temperature: $21 \pm 2^{\circ} \mathrm{C}$ (see additionally abbreviations section)

was the pattern of its decline sinusoidal, however. Rather, after 14 days it resembled the decline observed for the $60 / 40,70 / 30$, and $80 / 20 \mathrm{P} 2 / \mathrm{MC} \mathrm{L}-\mathrm{A}$ specimens, the rate of whose increase in diameter was attributed especially to $\operatorname{ett}-r f$ (Fig. 6). Therefore, the steepest decline, recorded between days 1 and 14, had necessarily to have been primarily the result of ett-rf (Fig. 5). That meant that the $8.73 \% \mathrm{C}_{3} \mathrm{~A}$ in the $\mathrm{P} 1$ fraction $(60 \%)$ with which the $3.9 \%$ of $\mathrm{Al}_{2} \mathrm{O}_{3}^{r-}$ from the metakaolin $(33 \times 40 \%)$ in the $\mathrm{MC}$ fraction (which also contained $26.4 \%$ calcite) was mixed had also to have formed ett-rf and not ett-lf (Fig. 5). This was so because here the specific pozzolanic activity generated by the aforementioned metakaolin fraction, plus the activity generated directly and nondirectly by the calcite fraction, must have been sufficient to ensure total rather than the partial stimulation observed in the sister $80 / 20$ and $70 / 30 \mathrm{P} 1 / \mathrm{MC}$ specimens (Table 4 and Fig. 5). This is supported by the following:

- experimental proof of the foregoing has been reported for metakaolin of a different origin (Talero 2002, 2005, 2007, 2009, 2010, 2011c), and

- this new study has also showed that $\Delta \varnothing(\%)$ in L-A specimen $60 / 40 \mathrm{P} 1 / \mathrm{MC}$ grew considerably and rapidly to the age of 90 days, nearly flattening thereafter through the end of the trial [Fig. 1(a)], and that its sister 70/30 L - A specimen behaved similarly, although rising somewhat less steeply. The increase in diameter of the other sister, the 80/20 specimen, in contrast, like the diameter of the pure P1 (whose early age $\Delta \varnothing(\%)$ was induced by ett-lf only and subsequently and through the end by ett-vlf), continued to grow. For further details, see questions (B) in the following.

All of this would be further ratified by the VNP curves for the specimens (Fig. 3), for while the curve for the 60/40 P1/MC L-A specimen bore no resemblance whatsoever to the curve for P1 (one was concave and the other convex), the curves for its sister $70 / 30$ and 80/20 specimens did resemble the one for P1. In the P2/MC family, in contrast, only the $80 / 20 \mathrm{~L}-\mathrm{A}$ specimen had a VNP curve that looked like the curve for P2 because the curves for its sister
60/40 and 70/30 P2/MC specimens exhibited diametrically opposite behavior during the first 90 days of the trial. These differences in behavior must have necessarily been due, especially, to the formation of ett-rf (Fig. 6). The conclusion drawn from the foregoing is that because in the $\mathrm{P} 1 / \mathrm{MC}$ family the sole curve that was unlike the $\mathrm{P} 1$ curve was the one generated by $60 / 40 \mathrm{P} 1 / \mathrm{MC}$, the primary cause must have been ett-rf formation as well. Here, however, the origin must have been the $3.9 \% \mathrm{Al}_{2} \mathrm{O}_{3}^{r-}$ from the $\mathrm{MC} 40 \%$ fraction (containing $26.4 \%$ calcite) plus the $8.73 \% \mathrm{C}_{3} \mathrm{~A}$ present in the $\mathrm{P} 1$ fraction $(60 \%)$ with which it was mixed (Fig. 5).

1. Questions regarding parameter $\Delta \varnothing(\%)$ versus time (Fig. 1):

$a$. Throughout the L-A test, the $\Delta \varnothing(\%)$ curves for the P1/MC and $\mathrm{P} 2 / \mathrm{MC}$ families of cements could be likened to a twostep or one-step stairway, respectively, in which each step had a somewhat slanted riser and a horizontal tread. The interpretation follows:

(1) The first step began at the age of 1 day and ended after 7 days, when the diameter ceased to increase. The origin of this first step was, in part, MC-induced expansive synergic effect (ESE) (Tables 7 and 8 ) in the $\mathrm{C}_{3} \mathrm{~A}$ in P1 (11.288, 9.877, and $8.466 \%$ for the $80 / 20,70 / 30$, and 60/40 blends, respectively) (Talero 2010, 2011a, c). It was also attributable to the direct (Rahhal and Talero 2005), nondirect (Rahhal et al. 2012), and above all indirect (Talero and Rahhal 2009; Talero 2011a, c, 2012) stimulation of the sulfate-mediated hydration of the metakaolin fraction, induced by the high, early, and rapid specific pozzolanicity generated by its $\mathrm{Al}_{2} \mathrm{O}_{3}^{r-}$ content. Lastly, the substantial calcite fraction also contributed to direct and nondirect stimulation.

(2) The second step began at 28 days and ended after 90 , after which the diameter ceased to increase through the end of the trial. This second step must have been prompted by direct and nondirect stimulation of sulfate-mediated hydration induced under these conditions by the substantial calcite fraction in the MC. Further to 
the Frattini test findings and the experimental results of a prior study with metakaolin of a different origin (Talero 2007), the growth in diameter prompted by the metakaolin via indirect stimulation ceased after 28 days, when this component was practically depleted (Table 4 and references Talero and Rahhal 2009; Talero 2007, 2009, 2010, 2011a, c, 2012). In contrast, calcite-induced direct and nondirect stimulation rose uninterruptedly because its presence grew with time due to portlandite carbonation, although here the stimulus affected the $\mathrm{C}_{4} \mathrm{AF}$ (4.264, 3.731, and $3.198 \%$, respectively) in the P1 with which the MC was blended.

Further to that hypothesis, assuming that the $\mathrm{C}_{3} \mathrm{~A}$ content in $\mathrm{P} 1$ were not 14.11 but $0.00 \%$, the $\Delta \varnothing(\%)$ versus age curves for cement blends $80 / 20,70 / 30$, and $60 / 40$ P1/MC would have had not two steps but only one, i.e., with a $\mathrm{C}_{3} \mathrm{~A}(\%)$ content of zero no ESE would have been induced in any of the three blends between days 1 and 7 (or sustained through the age of 28 days). Rather, hydration would have been stimulated directly and nondirectly after the latter age only, to which the considerable amount of calcite in the MC would have contributed exclusively. The reason is that the early age indirect stimulation prompted by the also early, high, and fast specific pozzolanic activity of the metakaolin fraction (Rahhal and Talero 2014) in MC could not continue at later ages, for it would have been depleted after 28 days (Table 4). And that is exactly the pattern adopted by the $\Delta \emptyset(\%)$ versus age curves for the $\mathrm{P} 2 / \mathrm{MC}$ blended cements, which are characterised by a single step because the $\mathrm{C}_{3} \mathrm{~A}(\%)$ content in their $\mathrm{PC}$ was $0.00 \%$, whereas the $\mathrm{C}_{4} \mathrm{AF}$ content stimulated was $10.91 \%$. The following arguments are set out to dispel any further doubts about the justification of this single step.

(3) If the MC waste had not been mixed with both PCs, P1 and P2, direct and nondirect stimulation of sulfatemediated P1 and P2 hydration by its calcite fraction, approximately $66 \%$, would not have occurred. Therefore, the $\Delta \varnothing(\%)$ versus time curves for their L-A specimens would have been proportionally lower and much less smooth, respectively, and not just at early ages but especially at the end of the trial, i.e., during the unique step. That is exactly, once again, the pattern adopted by the $\Delta \varnothing(\%)$ versus age curves for both pure PC, P1 and P2 (Figs. 1 and 2).

(4) After mixing, if the MC waste had been completely inert, in terms of sulfate resistance, the curves $\Delta \emptyset(\%)$ versus time for the respective L-A specimens would have had tobe parallel to and lower than the respective pure PC, P1 and $\mathrm{P} 2$, curves. The curves were neither parallel to nor lower than the respective pure PC, P1 and P2, curves, however (Figs. 1 and 2).

In a nutshell, the explanation for these findings is that $\mathrm{C}_{4} \mathrm{AF}$ hydrates at a considerably slower pace than $\mathrm{C}_{3} \mathrm{~A}$ (and also $\mathrm{C}_{3} \mathrm{~S}$ ).

$b$. Now that the veracity of the aforementioned hypothesis has been substantiated, a further question must be posed. The $\Delta \varnothing(\%)$ values of the $80 / 20,70 / 30$, and $60 / 40$ P2/MC blend cements were actually or potentially greater at the end of the test than for the respective P1/MC family L-A specimens. Why should that be, given that those values were considerably lower up to the age of 7 days and the sum of the $\mathrm{C}_{3} \mathrm{~A}+\mathrm{C}_{4} \mathrm{AF}$ content, at $19.44 \%$, was greater in PC P1 than the $10.19 \%$ in P2? At least two reasons can be put forward:
(1) The absence of $\mathrm{C}_{3} \mathrm{~A}$ in all the P2 blends prevented the metakaolin from the respective fraction of MC from generating ESE. As a result, the diameter of their L-A specimens remained more stable for the first 7 days of the trial, i.e., they did not exhibit the substantial expansion undergone by the $80 / 20,70 / 30$, and 60/40 P1/MC specimens in the first 7 days.

(2) Moreover, P2 had a $79.43 \% \mathrm{C}_{3} \mathrm{~S}$ content. Unlike $\mathrm{C}_{3} \mathrm{~A}$, $\mathrm{C}_{3} \mathrm{~S}$ is not affected by sulfate attack, although it is impacted by the water bearing these ions, by which it is hydrated, prompting subsequent setting and hardening. It is, in fact, the portland clinker component which, barring $\mathrm{C}_{3} \mathrm{~A}$, hydrates and sets fastest. This must indisputably generate very strong opposing stresses throughout the L-A specimen between the expansive tendencies of ettvlf, whose origin lies in $\mathrm{C}_{4} \mathrm{AF}$ (Fig. 7), on the one hand [indirectly, due to indirect stimulation at early ages, especially of metakaolin fraction (Talero 2009) in MC, and/or directly, due to direct (Rahhal and Talero 2005) and nondirect (Rahhal et al. 2012) stimulation of calcite fraction in $\mathrm{MC}]$, and on the other, to the intrinsic setting and hardening induced by the high $\mathrm{C}_{3} \mathrm{~S}$ content. The result of such stress would be greater expansion despite the fact that the sum of $0.00 \% \mathrm{C}_{3} \mathrm{~A}+10.10 \% \mathrm{C}_{4} \mathrm{AF}$ is smaller than the $14.11+5.33 \%$ in $\mathrm{P} 1$. This was further confirmed by the fact that the $\mathrm{VNP}_{7 d}$ for the $80 / 20 \mathrm{P} 2 / \mathrm{MC} \mathrm{L}-\mathrm{A}$ specimen, at $17.5 \mathrm{~mm}$, was the smallest of all the values recorded (the largest, $23 \mathrm{~mm}$, was found for specimen 80/ $20 \mathrm{P} 1 / \mathrm{MC}$ ), while at the same time it exhibited the highest $\mathrm{VNP}_{90 d}$ value: $40 \mathrm{~mm}$. Further to this hypothesis, then, if the $\mathrm{MC}-\mathrm{P} 2$ replacement rate had been nil, the first VNP value for the L-A specimen would have begun to be non-nil much later and the initial values would have been much smaller. That is precisely what was observed in this study, inasmuch as the first VNP value, $9.99 \mathrm{~mm}$, was found for the L-A specimen after 365 days [Fig. 3(b)]. Up until that age the hydraulicity of its $79.43 \% \mathrm{C}_{3} \mathrm{~S}$ content and concomitant hardening proved to be a stronger force than $e t t$ - $v l f$-induced expansion because the amount of ett-vlf formed would have still been insufficient (Talero 2009). That notwithstanding, both behaviors denoted the detrimental effect of blending MC with any PC-exposed to sulfates. Again, if any doubt might remain about the veracity of this hypothesis, note that the $\mathrm{VNP}_{365 d}$ for the $\mathrm{L}-\mathrm{A}$ patty of $\mathrm{P} 3$, with $11.75 \% \mathrm{C}_{4} \mathrm{AF}, 58.19 \% \mathrm{C}_{3} \mathrm{~S}$, $19.46 \% \mathrm{C}_{2} \mathrm{~S}$ and $0.00 \% \mathrm{C}_{3} \mathrm{~A}$ (Table 1) was $7.83 \mathrm{~mm}$, i.e., slightly lower than the value for $\mathrm{P} 2$, which is consistent with this hypothesis. Nonetheless, once ettringite forms from any of the three origins discussed $\left(\mathrm{Al}_{2} \mathrm{O}_{3}^{\mathrm{r}-}\right.$ and/or $\mathrm{C}_{3} \mathrm{~A}$ or $\mathrm{C}_{4} \mathrm{AF}$ ), its inherent expansiveness and hence detrimental effect always prevails over the hardening of the $\mathrm{L}-\mathrm{A}$ specimen due to $\mathrm{C}_{3} \mathrm{~S}$ hydraulicity. That does not mean, however, that the harm is not proportional to the total amount formed from any of the aforementioned origins, for the greater or lesser hardening of the cementitious material in which the mineral forms is a determinant in this regard [Figs. 1( $a$ and b), 3(a and b), and 4].

The foregoing proves that when hydrated in the presence of sulfates, $\mathrm{C}_{4} \mathrm{AF}$ does not nor can it assume the role of $\mathrm{C}_{3} \mathrm{~A}$, either alone or in the presence of $\mathrm{C}_{3} \mathrm{~A}$; in other words, it logically never behaves like $\mathrm{C}_{3} \mathrm{~A}$.

Therefore, the calcined paper sludge waste MC used was the major cause of the very poor resistance to sulfate attack in P1/MC 
and $\mathrm{P} 2 / \mathrm{MC}$ blends, primarily because this sulfate attack was intense and speedy. The reason was that the $\mathrm{Al}_{2} \mathrm{O}_{3}^{r-}$-containing approximately $33 \%$ metakaolin fraction in the MC used would yield ett-rf, the chief direct and indirect cause of the expansive synergic effect (ESE), generated by the ettringite whose origin was $\mathrm{Al}_{2} \mathrm{O}_{3}^{r-}$ and $\mathrm{C}_{3} \mathrm{~A}$ (Tables 7 and 8).

To put it another way, ESE would have been enhanced by the ettringite precipitating from the $\mathrm{C}_{3} \mathrm{~A}$ (Talero 2007, 2010, 2011a, c) (Tables 7 and 8) while the stimulation of sulfate-mediated P1 hydration would have been induced by the $\mathrm{Al}_{2} \mathrm{O}_{3}^{r-}$ when converted into ett-rf in this gypsum and water environment. This stimulation would be both direct (Rahhal and Talero 2005) and nondirect (Rahhal et al. 2012), but mostly indirect (Talero and Rahhal 2009; Talero 2011a, c, 2012), given the prior development of high and early pozzolanicity in the MC, because of its approximately $33 \%$ metakaolin content. That in turn favored more intense and speedier stimulation of the sulfate-mediated hydration of the $\mathrm{C}_{3} \mathrm{~A}$ present in the P1 with which the MC was mixed. The resulting ESE would be proportional to the degree of pozzolanicity of the metakaolin in the $\mathrm{MC}$, forming ett-rf in this gypsum medium. More precisely, the $\mathrm{Al}_{2} \mathrm{O}_{3}^{r-}$, when converted into ett-rf, was the chief direct and indirect cause of the ESE originated, for which reason (Talero 2011a, c) its very early pozzolanic activity must be regarded as being more specific than generic in the intense and swift hydration of the sulfate in $\mathrm{C}_{3} \mathrm{~A}$. The respective $\mathrm{C}_{3} \mathrm{~S}$ component in $\mathrm{P} 1$ was not affected by any of these developments.

Whereas in the MC, such direct and nondirect stimulation always logically overlapped with indirect stimulation, certain circumstances favored both:

- In all certainty the approximately 33\% metakaolin fraction would induce such stimulation (Talero and Rahhal 2009; Talero 1986, 2011c, 2012),

- At the same time, the approximately $66 \%$ calcite filler fraction would very likely favor these pathways (Rahhal and Talero 2005; Talero 2013; Talero et al. 2009; Calleja and Aguanell 1980). Direct stimulation would be dually present: stimulating sulfate-mediated $\mathrm{C}_{3} \mathrm{~A}$ hydration in the OPC when the surface of its particles were moistened by the mixing water and forming tri-, mono-, or hemi-carboaluminate hydrates, likewise sourced from the $\mathrm{C}_{3} \mathrm{~A}$ in $\mathrm{P} 1$. Indirect stimulation would also take place, albeit logically in the absence of pozzolanic activity, as logical, but in the presence of a low sulfate concentration (Rahhal et al. 2012; Martín-Luengo 1997). Here the formation of calcium mono-carboaluminate hydrate would be favored over the formation of AFm whose $\mathrm{SO}_{3}$ content would be transformed into ettringite (Rahhal et al. 2012; Talero 2013). That would ultimately cause greater expansion and perhaps constitute a thaumasite precursor at more mature ages (Crammond 2003; Talero 1989). Nondirect stimulation of sulfate-mediated hydration (Rahhal et al. 2012) of the $C_{3} S$ as well as the $C_{2} S$ present in $P 1$, must not be left out of the equation, however. Rather, account must be taken of the comparative significance of the calcite filler fraction and the metakaolin fraction taken together for the progress of the sulfate-mediated hydration of the $\mathrm{C}_{3} \mathrm{~A}$ present in $\mathrm{P} 1$ with which the MC was mixed.

Summing up, the adverse effect of mixing MC with P1 exposed to sulfate attack explains the expansive synergic effect (ESE) originated (Tables 7 and 8) by the coprecipitation of two sources of rapid-forming ettringite (ett-rf) in the gypsum and water environment, found in the $\mathrm{L}-\mathrm{A}$ specimens in this study: the $\mathrm{C}_{3} \mathrm{~A}$ in $\mathrm{P} 1$ and the reactive alumina $\left(\mathrm{Al}_{2} \mathrm{O}_{3}^{r-}\right)$ present in the $\mathrm{MC}$. Nonetheless, the calcite fraction must have also contributed very significantly to this effect because such coprecipitation was also induced by its direct and nondirect stimulation of sulfate hydration. Moreover, indirect stimulation involving both the calcite and the $\mathrm{Al}_{2} \mathrm{O}_{3}^{r-}(\%)$ in the metakaolin present in the $\mathrm{MC}$ would have been the prevalent pathway, affecting the $\mathrm{C}_{3} \mathrm{~A}(\%)$ in the $\mathrm{P} 1$ with which the $\mathrm{MC}$ was blended. None of these interactions was observed for $\mathrm{C}_{3} \mathrm{~S}$, however. These findings also confirm that despite its large calcite content, the MC waste tested exhibited sufficient pozzolanic activity and sulfate-mediated hydration reactivity to be regarded as an artificial pozzolan.

\section{XRD Results}

The XRD results (Figs. 5-8, Tables 5 and 6) confirmed the behavior described earlier, for from the outset of the L-A test, the higher the $\mathrm{PC} / \mathrm{MC}$ replacement ratio, the greater was the amount of ett-rf formed. In other words, this particular type of ettringite, sourced from the $\mathrm{Al}_{2} \mathrm{O}_{3}^{r-}$ content $(9.67 \%)$ in the metakaolin fraction of the $\mathrm{MC}$ waste, formed especially in the early stages of the test (Rahhal and Talero 2014). That behavior was also clearly observed for all

Table 5. XRD Analysis: First Peak Intensity of Ettringite $\left(9.080^{\circ} 2 \theta\right)$ and Thaumasite $\left(9.147^{\circ} 2 \theta\right)$; Age: 7, 28, and 1,200 Days

\begin{tabular}{|c|c|c|c|c|}
\hline $\begin{array}{l}\text { Portland } \\
\text { cement }\end{array}$ & $\begin{array}{l}\text { Age } \\
\text { (days) }\end{array}$ & $\begin{array}{c}\text { P"X"/"MC" } \\
(\% / \%)\end{array}$ & $\begin{array}{c}\text { Intensity } \\
\text { (first peak } \\
\text { ettringite) } \\
\text { (a.u.) } \\
\text { comparative }\end{array}$ & $\begin{array}{c}\text { Intensity } \\
\text { (first peak } \\
\text { thaumasite) } \\
\text { (a.u.) } \\
\text { comparative }\end{array}$ \\
\hline \multirow[t]{12}{*}{ P1 } & \multirow[t]{4}{*}{7} & $\mathrm{P} 1 / \mathrm{MC}(100 / 00)$ & 426 & - \\
\hline & & $\mathrm{P} 1 / \mathrm{MC}(80 / 20)$ & + & - \\
\hline & & $\mathrm{P} 1 / \mathrm{MC}(70 / 30)$ & ++ & - \\
\hline & & $\mathrm{P} 1 / \mathrm{MC}(60 / 40)$ & +++ & - \\
\hline & \multirow[t]{4}{*}{28} & $\mathrm{P} 1 / \mathrm{MC}(100 / 00)$ & 969 & - \\
\hline & & $\mathrm{P} 1 / \mathrm{MC}(80 / 20)$ & + & - \\
\hline & & $\mathrm{P} 1 / \mathrm{MC}(70 / 30)$ & ++ & - \\
\hline & & $\mathrm{P} 1 / \mathrm{MC}(60 / 40)$ & +++ & - \\
\hline & \multirow[t]{4}{*}{1,200} & $\mathrm{P} 1 / \mathrm{MC}(100 / 00)$ & 1,424 & 2,056 \\
\hline & & $\mathrm{P} 1 / \mathrm{MC}(80 / 20)$ & + & - \\
\hline & & $\mathrm{P} 1 / \mathrm{MC}(70 / 30)$ & $\approx$ & -- \\
\hline & & $\mathrm{P} 1 / \mathrm{MC}(60 / 40)$ & + & --- \\
\hline \multirow[t]{12}{*}{$\mathrm{P} 2$} & \multirow[t]{4}{*}{7} & $\mathrm{P} 2 / \mathrm{MC}(100 / 00)$ & 0 & - \\
\hline & & $\mathrm{P} 2 / \mathrm{MC}(80 / 20)$ & + & - \\
\hline & & $\mathrm{P} 2 / \mathrm{MC}(70 / 30)$ & ++ & - \\
\hline & & $\mathrm{P} 2 / \mathrm{MC}(60 / 40)$ & +++ & - \\
\hline & \multirow[t]{4}{*}{28} & $\mathrm{P} 2 / \mathrm{MC}(100 / 00)$ & 340 & - \\
\hline & & $\mathrm{P} 2 / \mathrm{MC}(80 / 20)$ & + & - \\
\hline & & $\mathrm{P} 2 / \mathrm{MC}(70 / 30)$ & ++ & - \\
\hline & & $\mathrm{P} 2 / \mathrm{MC}(60 / 40)$ & +++ & - \\
\hline & \multirow[t]{4}{*}{1,200} & $\mathrm{P} 2 / \mathrm{MC}(100 / 00)$ & 707 & 1,880 \\
\hline & & $\mathrm{P} 2 / \mathrm{MC}(80 / 20)$ & + & +++ \\
\hline & & $\mathrm{P} 2 / \mathrm{MC}(70 / 30)$ & ++ & ++ \\
\hline & & $\mathrm{P} 2 / \mathrm{MC}(60 / 40)$ & ++ & + \\
\hline
\end{tabular}

Table 6. XRD Analysis: First Peak Intensity of Ettringite $\left(9.080^{\circ} 2 \theta\right)$ and Thaumasite $\left(9.147^{\circ} 2 \theta\right)$. Age: 18 Years

\begin{tabular}{lcccc}
\hline Portland & Age & $\begin{array}{c}\text { L-A } \\
\text { specimen } \\
\text { sempling } \\
\text { (level) }\end{array}$ & $\begin{array}{c}\text { Intensity } \\
\text { (first peak } \\
\text { ettringite) } \\
\text { (a.u.) }\end{array}$ & $\begin{array}{c}\text { Intensity } \\
\text { (first peak } \\
\text { thaumasite) } \\
\text { (a.u.) }\end{array}$ \\
\hline P2 & 18 & Upper & +++ & ++ \\
& & Central & ++ & + \\
P3 & Lower & + & ++ \\
& Upper & +++ & ++ \\
& & Central & ++ & + \\
& Lower & + & ++ \\
\hline
\end{tabular}


Table 7. Proof of ESE Based on the Relative Ettringite Content in Each L-A Specimen, Obtained by XRD Analysis

\begin{tabular}{|c|c|c|c|c|c|c|c|}
\hline POZC needed for calculation & $\begin{array}{c}\text { Age } \\
\text { (days) }\end{array}$ & $\begin{array}{l}\left(a_{1}\right) \\
(\text { a.u. })\end{array}$ & $\begin{array}{l}\left(a_{2}\right) \\
\text { (a.u.) }\end{array}$ & $\begin{array}{c}(b) \\
\text { (a.u.) }\end{array}$ & $\begin{array}{c}{\left[\left(a_{1}\right)+(b)\right]} \\
\text { (a.u.) }\end{array}$ & $\begin{array}{c}(c) \\
\text { (a.u.) }\end{array}$ & $(d)$ \\
\hline $60 / 40 \mathrm{P} 1 / \mathrm{MC}$ and $\mathrm{P} 2 / \mathrm{MC}$ & 7 & 255.6 & 000.0 & 939.0 & $1,194.6$ & $1,510.0$ & 1.26-fold higher than the theoretical intensity \\
\hline $60 / 40 \mathrm{P} 1 / \mathrm{MC}$ and $\mathrm{P} 2 / \mathrm{MC}$ & 28 & 581.4 & 204.0 & $1,076.0$ & $1,657.4$ & $1,920.0$ & 1.61-fold higher than the theoretical intensity \\
\hline $60 / 40 \mathrm{P} 1 / \mathrm{MC}$ and $\mathrm{P} 2 / \mathrm{MC}$ & 1,200 & 854.4 & 424.0 & 451.8 & $1,306.2$ & $1,586.0$ & 1.21-fold higher than the theoretical intensity \\
\hline
\end{tabular}

Note: $\left(a_{1}\right)=60 \% \times$ intensity $_{x d}$ for the P1 specimen $\left(=426.0_{7 d}, 969.0_{28 d}\right.$, and 1,424.0 $0_{1200 d}$ a.u. $)=255.6_{7 d}, 581.4_{28 d}$, and $854.4_{1200 d}$ a.u.; $\left(a_{2}\right)=$ $60 \% \times$ intensity $_{x d}$ for the P2 specimen $\left(=000.0_{7 d}, 340.0_{28 d}\right.$, and $707.0_{1200 d}$ a.u. $)=000.0_{7 d}, 204.0_{28 d}$, and 424.2 a.u.; $(b)=$ intensity $x d$ for $40 \%$ $\mathrm{MC}$ waste $=$ Real intensity $y_{x d}$ for the $60 / 40 \mathrm{P} 2 / \mathrm{MC}$ specimen $\left(=939.0_{7 d}, 1,280.0_{28 d}\right.$, and 876.0 $0_{1200 d}$ a.u. $)-\left(a_{2}\right)=939.0_{7 d}, 1,076.0_{28 d}$, and 451.8 a.u.; $\left[\left(a_{1}\right)+(b)\right]=$ theoretical intensity for the $60 / 40 \mathrm{P} 1 / \mathrm{MC}$ specimen. $(c)=$ real intensity $x_{x d}$ for the $60 / 40 \mathrm{P} 1 / \mathrm{MC}$ specimen $\left(=939.0_{7 d}, 1,280.0_{28 d}\right.$, and $876.0_{1200 d}$ a.u.); $(d)=(c)$ was $n$-fold higher than $\left[\left(a_{1}\right)+(b)\right]$. The ettringite formed was quantified by integrating the intensities (a.u.) of the most characteristic reflection attributed to ettringite, which was located in $2 \theta-$ range $=9.08-9.14^{\circ} \mathrm{C}$.

Table 8. Proof of ESE in Le Chatelier-Anstett (L--A) Specimens (Cement Pastes with 33.3\% Gypsum)

\begin{tabular}{lllllllll}
\hline POZC needed for calculation & Parameter & $(a)$ & $\left(b_{1}\right)$ & $\left(b_{2}\right)$ & {$\left[(a)+\left(b_{1}\right)\right]$} & {$\left[(a)+\left(b_{2}\right)\right]$} & $(c)$ & $(d)$ \\
\hline $60 / 40 \mathrm{P} 1 / \mathrm{MC}$ and $\mathrm{P} 2 / \mathrm{MC}$ & $\Delta \emptyset_{7 d}(\%)$ & 3.55 & 6.69 & - & 10.24 & - & 31.13 & 3.0 -fold higher than the theoretical \\
$60 / 40 \mathrm{P} 1 / \mathrm{MC}$ and $\mathrm{P} 2 / \mathrm{MC}$ & $V c \emptyset_{1 d}[=\Delta \emptyset(\%) /$ day $]$ & 1.14 & - & 1.69 & - & 2.83 & 5.00 & 1.8 -fold higher than the theoretical \\
$80 / 20 \mathrm{P} 1 / \mathrm{MC}$ and $\mathrm{P} 2 / \mathrm{MC}$ & $\mathrm{VNP}_{7 d}(\mathrm{~mm})$ & 19.04 & - & 17.50 & - & 36.54 & 40.00 & 1.1 -fold higher than the theoretical \\
\hline
\end{tabular}

Note: $(a)=60 \% \times \Delta \emptyset_{7 \text { days }}(\%)$ for P1 specimen $(=5.93 \%)$ or $60 \% \times V c \emptyset_{1 d}(=1.90 \% /$ day $)$ or $80 \% \times \mathrm{VNP}_{7 d}(=19.04 \mathrm{~mm}=23.80 \mathrm{~mm} \times 80 \%)$. $\left(b_{1}\right)=\Delta \emptyset_{7 \text { days }}(\%)$ for $60 / 40 \mathrm{P} 2 / \mathrm{MC}$ specimen $-60 \% \times \Delta \emptyset_{7 \text { days }}(\%)$ for P2 specimen $=\Delta \emptyset_{7 \text { days }}(\%)$ for $40 \%$ of MC in $60 / 40 \mathrm{P} 2 / \mathrm{MC}$ specimen. $\left(b_{2}\right)=$ $40 \% \times V c \emptyset_{1 d}$ for $60 / 40 \mathrm{P} 2 / \mathrm{MC}$ specimen $=V c \emptyset_{1 d}$ for $40 \%$ of $\mathrm{MC}=V c \emptyset_{1 d}$ for $60 / 40 \mathrm{P} 2 / \mathrm{MC}=1.69 \% /$ day because $V c \emptyset_{1 d}$ for $\mathrm{P} 2$ specimen $=0.0(\%) /$ day; $\mathrm{VNP}_{7 d}$ for $20 \%$ of MC: $17.5 \mathrm{~mm}$. [(a) $\left.+\left(\mathrm{b}_{1}\right)\right]=$ theoretical $\Delta \emptyset_{7 \text { days }}(\%)$ for $60 / 40 \mathrm{P} 1 / \mathrm{MC}$. $\left[(a)+\left(b_{2}\right)\right]=$ theoretical $V c \emptyset_{1 d}$ for $60 / 40 \mathrm{P} 1 / \mathrm{MC}$ or theoretical $\mathrm{VNP}_{7 d}$ for $70 / 30$ and $80 / 20 \mathrm{P} 1 / \mathrm{MC}$ and $\mathrm{P} 2 / \mathrm{MC}$, respectively. $(c)=$ Real value. $(d)=(c)$ was $n$-fold higher than $\left[(a)+\left(b_{1}\right)\right]$ or than $\left[(a)+\left(b_{2}\right)\right]$.

the cements prepared with $\mathrm{P} 2$, which contained $0.00 \%$ of $\mathrm{C}_{3} \mathrm{~A}$. Moreover, the expansive synergic effect (ESE) (Table 7) induced by the specific pozzolanic activity of the aforementioned $\mathrm{Al}_{2} \mathrm{O}_{3}^{r-}$, was corroborated by the XRD patterns for $\mathrm{P} 1\left(14.11 \% \mathrm{C}_{3} \mathrm{~A}\right)$ and more firmly by the diffractograms for the blended P1/MC cements, in which the effect was more intense at higher replacement ratios (Tables 5-8). This circumstance also stimulated the formation rate of $\mathrm{C}_{3} \mathrm{~A}$-origin ettringite, having converted this type of ettringite into ett-rf, like its counterpart sourced from $\mathrm{Al}_{2} \mathrm{O}_{3}^{r-}$ (Talero 1986, 2009, 2011c; Rahhal and Talero 2014). In short, if the MC waste had previously generated sufficient pozzolanic activity, none of the ettringite from the $\mathrm{C}_{3} \mathrm{~A}$ in $\mathrm{P} 1$ would be ett-lf, but ett-rf only. Otherwise, only part of that possible total amount of ettringite would be ett-rf, and such part would be proportional to the amount of pozzolanic activity previously exhibited by the respective MC fraction in P1/MC. This process would continue until the pozzolanic activity of the respective $\mathrm{MC}$ fraction was depleted. By that time, all the $\mathrm{C}_{3} \mathrm{~A}$ may have been converted into ett-rf; if not, any remaining $\mathrm{C}_{3} \mathrm{~A}$ would be transformed into ett-lf (Talero 2011a, c).

The opposite behavior was observed for the $\mathrm{SiO}_{2}^{r-}(16.17 \%)$ in the metakaolin found in the MC. Although it is qualitatively similar to the $\mathrm{SiO}_{2}^{r-}$ in silica fume, diatomite, and opaline stone, which protect PC from sulfate attack (Talero 2009, 2011c; Martín-Luengo 1997) when added in suitable amounts, here it failed to provide an effective safeguard against the adverse effects of specific $\mathrm{Al}_{2} \mathrm{O}_{3}^{r-}$ behavior in any of the blended cements tested exposed to gypsum attack.

When the $\mathrm{C}_{3} \mathrm{~A}(\%)$ content was zero, the chemical reaction yielding very slow forming ettringite [ett-vlf, sourced from $\mathrm{C}_{4} \mathrm{AF}$, also present in the PCs tested (Rahhal et al. 2010)] in the L-A specimens took place largely after the first 90 or even 180 days of the test. The $\Delta \emptyset_{180-730 d}$ and $\mathrm{VNP}_{180-730 d}$ values for unblended sulfateresistant $\mathrm{P} 2$ and $\mathrm{P} 3$ could also be attributed to that circumstance. Consequently, the behavior of the 180- to 730-day L-A specimens was not representative of the actual behavior in real structures. For the present intents and purposes, only $\Delta \emptyset(\%)$ readings for 28-day or younger samples must be considered, as explained in earlier papers (Talero 1986, 1989, 2002) and in the present study, in light of the $V c \varnothing$ findings.
In short, this study provides insight into the scientific and technical implications of seven prior articles (Talero 2009, 2010, 2011a, c; Rahhal and Talero 2014). Nevertheless, the relative contributions to the adverse effects caused by the two fractions present in $\mathrm{MC}$ waste-calcite, approximately $66 \%$, and metakaolin, approximately $33 \%$ - via induction of an expansive synergic effect (ESE) in cements containing artificial pozzolan MC when exposed to sulfate attack are still open to question. Although this issue was not the object of the present study, should the answer prove to be affirmative, the quantitative participation of the calcite and metakaolin fractions in the ESE would be a matter worth exploring in greater depth, as was done when metakaolin (MK) alone was involved (Talero 2002, 2005, 2007, 2009, 2010, 2011a, c; Rahhal and Talero 2014). Such quantification for systems in which metakaolin is mixed with quartz instead of calcite filler will in fact be addressed in future research.

Finally, an additional effect may have arisen: Thaumasite may have formed in mature [1,200-day, Figs. 1(b) and 7(b)] and very mature (18-year, Fig. 8) L-A specimens. Its origin would have been the calcite present in the MC studied [Fig. 7(b)] or the synthetic calcite (the end product of the portlandite previously generated during $\mathrm{P} 1, \mathrm{P} 2$, and $\mathrm{P} 3$ hydration) and $\mathrm{C}_{3} \mathrm{~S}$ and $\mathrm{C}_{2} \mathrm{~S}$, and more precisely, the sulfate, carbonate, and C-S-H gel sourced from $\mathrm{C}_{3} \mathrm{~S}$ and $\mathrm{C}_{2} \mathrm{~S}$ (Fig. 8).

The approximately $66 \%$ calcite present in the MC studied here actually constituted limestone filler and was the internal source of the carbonate ions needed for thaumasite formation (Fig. 7). Whether the mineral formed from ettringite or from the sulfate and carbonate/ C-S-H gel interaction could not be ascertained, however.

Moreover, according to the present findings, materials made with sulfate-resistant portland cement (Blondiau 1961; Bensted 2003; Crammond 2003; Skaropoulou et al. 2009; Nobst and Stark 2003; Collet et al. 2004; Liu et al. 2013) are also susceptible to this type of sulfate attack and have been shown to be vulnerable to thaumasite sulfate attack as well [Figs. 3(b), 4(b and c), and 8 and Tables 5 and 6], even at $21 \pm 2^{\circ} \mathrm{C}$.

Furthermore, in the PC/MC L-A specimens, which contained limestone filler (approximately 66\% calcite in the MC used), the reaction front advanced inward during the attack, leading first to 


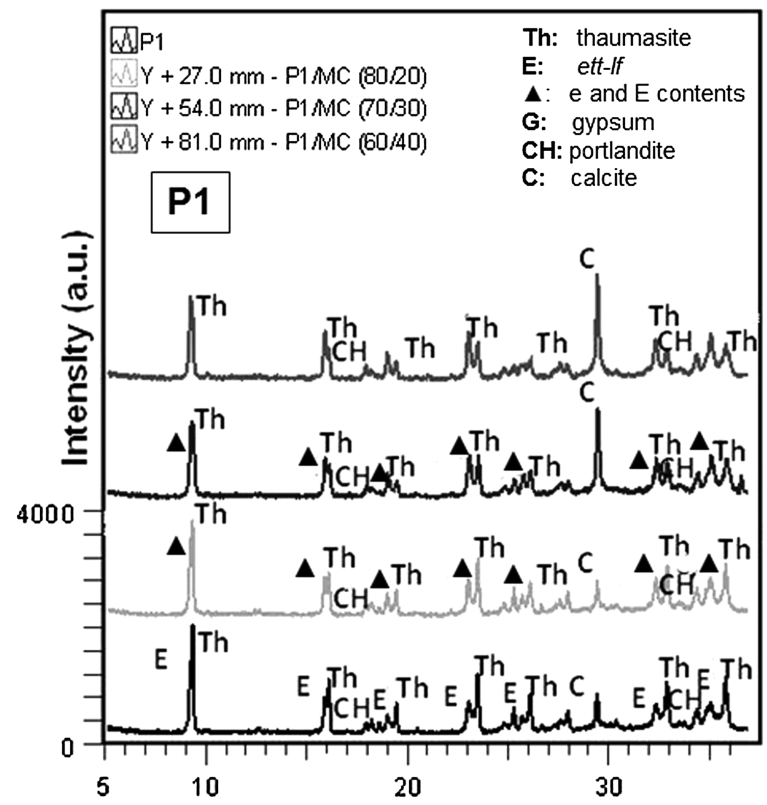

(a)

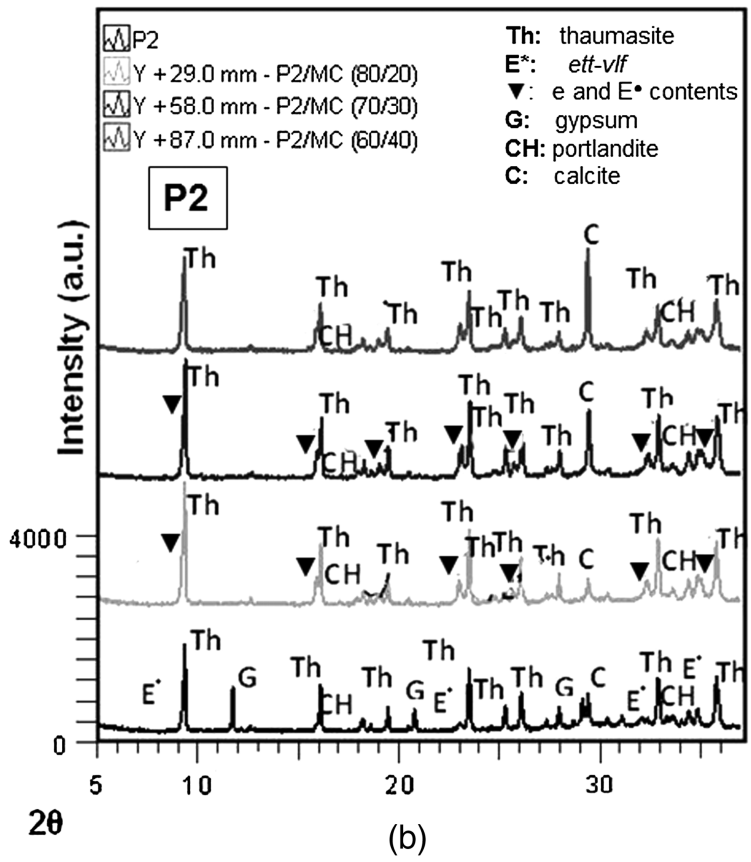

(b)

Fig. 7. XRD patterns for (a) P1 and (b) P2 and their 1,200-day MC blended cements; temperature: $21 \pm 2^{\circ} \mathrm{C}$ (see additionally abbreviations section)
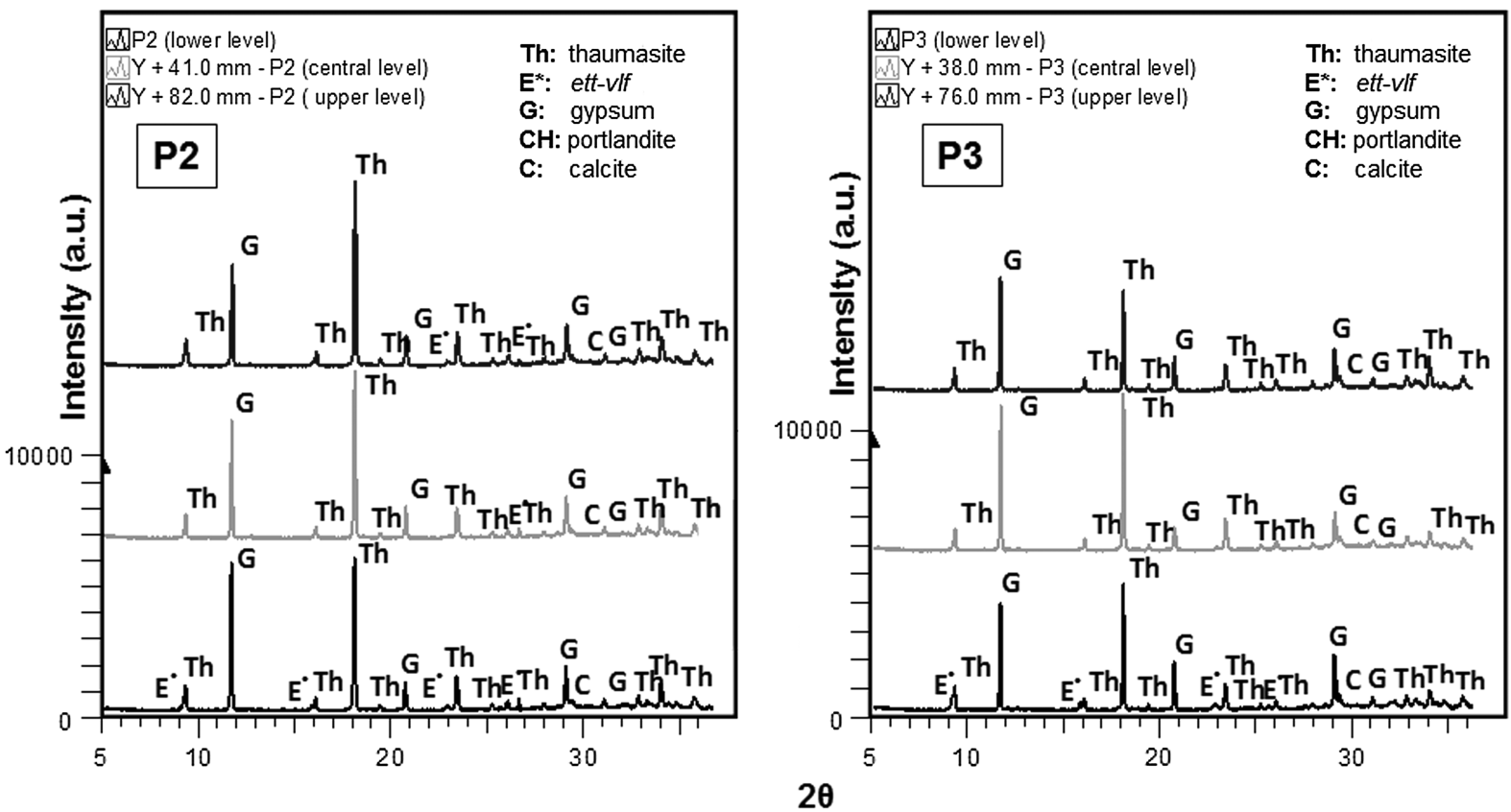

Fig. 8. XRD patterns for plain 18-year SRPC P2 and P3; temperature: $15 \pm 1{ }^{\circ} \mathrm{C}$ (see additionally abbreviations section)

ettringite (Figs. 5 and 6) and ultimately to thaumasite formation (Fig. 7). L-A paste decalcification as a result of pozzolanic activity (attributable to the $33 \% \mathrm{MK}$ in the MC) induced the breakdown of the C-S-H gel, the source of the silica required (Fig. 7). The reaction sequence in cements bearing limestone fillers (all the PC/MCs studied here must be regarded as "limestone filler cements" as well as blended cements) was essentially the same as in P1 and P2 at $21 \pm$ $2^{\circ} \mathrm{C}$ (Table 5 and Fig. 7) and as in $\mathrm{P} 2$ and $\mathrm{P} 3$ at $15 \pm 1{ }^{\circ} \mathrm{C}$ (Table 6 and Fig. 8). The main difference is that at later stages, thaumasite formed (Table 6 and Fig. 7) as a result of the decomposition of the ettringite generated in the early stages of this study, at $21 \pm 2{ }^{\circ} \mathrm{C}$. The inference is that the $\mathrm{C}_{4} \mathrm{AF}(\%)$ in these cements may also play a role (Talero 2011c; Tosum et al. 2009), especially when the $\mathrm{C}_{3} \mathrm{~A}(\%)$ content is zero (Tables 5 and 6 and Figs. 7 and 8).

Thaumasite may also be detected in plain sulfate-resistant cements [P2 and $\mathrm{P} 3$ with zero $\mathrm{C}_{3} \mathrm{~A}(\%)$ ] with no limestone filler [Table 6 and Figs. 7(b) and 8], suggesting that the formation of ettringite from $\mathrm{C}_{4} \mathrm{AF}$ (Rahhal et al. 2010) may in such cases be a prerequisite for the formation of thaumasite at both $21 \pm 2{ }^{\circ} \mathrm{C}$ and $15 \pm 1{ }^{\circ} \mathrm{C}$. This also means that thaumasite formation is not restricted to low temperature environments and that the P2 and P3 L-A specimens studied were ultimately damaged primarily by thaumasite sulfate attack. 


\section{Conclusions}

The conclusions drawn from the findings discussed in this paper are summarized in the following.

1. Sulfate resistance declined in both types of $\mathrm{PC}$ as the proportion of MC in the blends rose, even in the sulfate-resistant (P2) paste, which when blended ceased to be even moderately sulfate resistant. Moreover, under the same conditions, P1 was attacked in the same situation much more actively and rapidly (rapid gypsum attack). None of the blended cements studied could be classified as sulfate resistant or even moderately sulfateresistant.

2. The adverse effect of mixing MC with PC exposed to sulfate attack can be attributed to the expansive synergic effect (ESE) originated by the coprecipitation of two sources of rapidforming ettringite (ett-rf) in the gypsum and water environment found in the $\mathrm{L}-\mathrm{A}$ specimens in this study: the reactive alumina $\left(\mathrm{Al}_{2} \mathrm{O}_{3}^{r-}\right)$ present in the $\mathrm{MC}$ and the $\mathrm{C}_{3} \mathrm{~A}$ in $\mathrm{P} 1$. Nonetheless, the calcite fraction must have also contributed very significantly to this effect. Such coprecipitation is likewise induced by direct and nondirect stimulation of sulfate hydration. Indirect stimulation, involving both the calcite and the $\mathrm{Al}_{2} \mathrm{O}_{3}^{r-}(\%)$ in metakaolin, would be the prevalent mechanism, affecting the $\mathrm{C}_{3} \mathrm{~A}(\%)$ in the $\mathrm{P} 1$ fraction with which the $\mathrm{MC}$ was blended. None of these interactions was observed for the $\mathrm{C}_{3} \mathrm{~S}$.

Hence, the pozzolanic activity observed for $\mathrm{MC}$ was also more specific than generic. Furthermore, despite its large calcite content, the MC studied exhibited sufficient hydration reactivity to be regarded as an artificial pozzolan. The present $\Delta \emptyset_{28 d}$ $\mathrm{L}-\mathrm{A}$ specimen findings confirmed that the sole origin of slowforming ettringite, ett-lf, is the $\mathrm{C}_{3} \mathrm{~A}(\%)$ present in the $\mathrm{PC}$, here in $\mathrm{P} 1$. Rapid-forming ettringite, ett-rf, on the contrary, may have two origins: the $\mathrm{Al}_{2} \mathrm{O}_{3}^{r-}$ in the approximately $33 \%$ metakaolin fraction in the $\mathrm{MC}$ studied and the $\mathrm{C}_{3} \mathrm{~A}$ in $\mathrm{P} 1$, but only when both are present in a common gypsum and water environment.

3. Thaumasite formation and thaumasite sulfate attack may appear when the cement bears a significant carbonate filler content (approximately $66 \%$ calcite in the MC studied), although they may also appear in the absence of any significant amount of calcite. Alternative sources of carbonate would seem to be associated with carbonation of the portlandite resulting from prior PC hydration.

4. The existence of a calcite filler (in the MC used) likewise proved to be unessential for the onset of thaumasite formation or thaumasite sulfate attack, for thaumasite was detected in both sulfate-resistant cements [P2 and P3 with zero $\mathrm{C}_{3} \mathrm{~A}(\%)$ ] containing no limestone filler. That in turn suggested that ettringite formation from $\mathrm{C}_{4} \mathrm{AF}$ may be a prerequisite to the formation of thaumasite at $21 \pm 2^{\circ} \mathrm{C}$. It also reveals that thaumasite formation is not restricted to low temperature environments and that the P2 and P3 L-A specimens studied were ultimately damaged primarily by thaumasite sulfate attack. Further research and experimentation will be needed to determine whether thaumasite formation or thaumasite sulfate attack are generated from very slow forming ettringite (ett-vlf) or $\mathrm{C}_{4} \mathrm{AF}$, or directly from sulfate and synthetic calcite/C-S-H gel interaction.

\section{Technical Implications and Final Considerations}

Despite conclusion 1 and due to the MC waste, if its chemical composition can be kept constant, hydraulic expansive cements, as defined in ASTM standard C845-90 (ASTM 1995), could be produced with $7.0 \% \mathrm{SO}_{3}$ and suitable prior water curing. Where the $\mathrm{SO}_{3}$ content is under $7.0 \%$, they may be regarded as nonshrinkage cements, i.e., with a suitable amount of $\mathrm{SO}_{3}<7.0 \%$, expansion in this new blended cement would be able to compensate for its hydraulic, thermal, or drying shrinkage. With a lower $\mathrm{SO}_{3}$ content, the cement could be regarded simply as a blended cement (in keeping with the $\Delta L(\%)$ versus time values found and quantified as per ASTM standard C452-68 (Talero 2011a, 2013) adapted by Talero (1986). Technologically speaking, the foregoing would be a beneficial consequence of ESE. In contrast, if the excess gypsum added to these blended cements is greater than $7.0 \%$, the result would be very detrimental, and the more excess gypsum, the greater the harm. Sulfate attack under such circumstances is so fast and aggressive that it can justifiably be termed rapid gypsum attack (Talero 1986, 2002, 2005, 2007, 2009, 2010, 2011c).

According to Spanish code for on-site cement acceptance RC-08 (2008), the MC studied cannot, however, be used in blended cement (CEM II/A-M or II/B-M) intended for sulfate-resistant concrete (self-compacting or otherwise) because of its very high metakaolin content, approximately $33 \%$. Given its high percentage of limestone filler, nor can it be used in concrete where the steel reinforcement must be protected from chloride attack or other chemical or aggressive agents such as carbonation or alkali aggregate reaction (Rahhal et al. 2012).

Pozzolan-induced ettringite has been shown to form at early ages (Talero 2009) for all portland cements with aluminic pozzolanic additions in chemical character w with a significant reactive alumina $\left[\mathrm{Al}_{2} \mathrm{O}_{3}^{r-}(\%)\right]$ content, as in the $\mathrm{MC}$ used $\}$. Such ettringite, known as rapid-forming ettringite or ett-rf, must be distinguished from slow-forming ettringite, ett-lf, sourced from the $\mathrm{C}_{3} \mathrm{~A}$ in $\mathrm{PC}$. The ett-rf form may be generated irrespective of the mineralogical composition of the $\mathrm{PC}$, as shown by the experiments with MC performed in this study. In this case, the poor sulfate resistance of the calcined paper sludge waste selected was attributable to its significant metakaolin content (approximately 33\%). Nonetheless, its approximately $66 \%$ calcite filler fraction should also play a key role in the rapid gypsum attack via direct (Rahhal and Talero 2005), nondirect (Rahhal et al. 2012), and indirect (Talero and Rahhal 2009; Talero 2011c, 2012) stimulation. Moreover, care must be taken in the manufacture of self-compacting concrete with the MC studied as a mineral addition because the early-age heat of hydration released by the blended cement would be comparable to a calorific synergic effect (Rahhal and Talero 2009a; Rahhal et al. 2010) resulting in overly high thermal and drying shrinkage.

\section{Acknowledgments}

The authors are grateful to the Colmen Paper-Papelera Peninsular Company for its kind support and to the MCYT (Spanish Government), by means of national project, ref. CTM2006-12551-C03-01. The physics-chemical characteristics and crystalline composition of each PC have been provided by their manufacturers.

\section{Notation}

The following symbols are used in this paper:

$\mathrm{E}=$ ett-lf $=$ slow-forming ettringite $=$ Ettringite that forms slowly from $\mathrm{C}_{3} \mathrm{~A}$ present in OPC $\mathrm{P} 1$. The term ett-lf is not intended to mean that this type of ettringite is always necessarily the product of slow formation when coprecipitating with ett-rf from the $\mathrm{Al}_{2} \mathrm{O}_{3}^{r-}$ present in the $\mathrm{MC}$ waste, but merely that in the latter circumstances, it formed from the $\mathrm{C}_{3} \mathrm{~A}(\%)$ present in the OPC P1 with which the MC waste was mixed (Talero 2002, 2005, 2007, 2009, 2010, 2011a, c; Rahhal and Talero 2014); 
$E^{\bullet}=$ ett-vlf $=$ very slow-forming ettringite $=$ Ettringite that forms from $\mathrm{C}_{4} \mathrm{AF}$ present in SRPC P2. The term ett-vlf is not intended to mean that this type of ettringite is always necessarily the product of very slow formation when coprecipitating with ett-rf from the $\mathrm{Al}_{2} \mathrm{O}_{3}^{r-}$ present in the $\mathrm{MC}$ waste, but merely that in the latter circumstances, it formed from the $\mathrm{C}_{4} \mathrm{AF}(\%)$ present in the SRPC P2 with which the MC waste was mixed (Rahhal and Talero 2014);

$\mathrm{e}=$ ett-rf $=$ rapid-forming ettringite $=$ Ettringite that forms rapidly from $\mathrm{Al}_{2} \mathrm{O}_{3}^{r-}$ present in the $\mathrm{MC}$ waste;

e and $\mathrm{E}=\mathrm{e}+$ ettringite contents, random but directly and indirectly proportional, respectively, to the specific pozzolanic activity originated at early ages, by the $\mathrm{Al}_{2} \mathrm{O}_{3}^{r-}$ of the metakaolin present in the respective $\mathrm{MC}$ waste fraction mixed with OPC P1 (Talero 2009, 2010, 2011a, c; Rahhal and Talero 2014);

e and $\mathrm{E}^{\bullet}=\mathrm{e}+\mathrm{E}^{\bullet}$ ettringite contents, random but directly and indirectly proportional, respectively, to the specific pozzolanic activity originated at early ages, by the $\mathrm{Al}_{2} \mathrm{O}_{3}^{r-}$ of the metakaolin present in the respective $\mathrm{MC}$ waste fraction mixed with SRPC P2 (Talero 2011c);

POZC $=$ blended cements 80/20, 70/30, and 60/40P1/MC and $\mathrm{P} 2 / \mathrm{MC}$;

$V c \varnothing=$ diameter growth rate $=\Delta \varnothing(\%) /$ day; and

$\Delta \varnothing=$ increase in diameter $(\%)$.

\section{References}

AENOR (Asociación Espaæola de Normalización y Certificación). (2005). "Methods for testing cement. V: Pozzolanicity test for pozzolanic cements." EN 196-5, Madrid, Spain.

AENOR (Asociación Espaæola de Normalización y Certificación). (2011). "Cement-Part 1: Composition, specifications and conformity criteria for common cements." EN 197-1, Madrid, Spain.

AENOR (Asociación Espaæola de Normalización y Certificación). (2012). "Standard: Métodos de ensayo de cementos. Análisis Químico: Determinación del dióxido de silicio $\left(\mathrm{SiO}_{2}\right)$ reactivo en los cementos, en las puzolanas y en las cenizas volantes." UNE 80-225, Madrid, Spain.

ASTM. (1995). "Standard specification for expansive hydraulic cement." ASTM C845-90, West Conshohocken, PA.

ASTM. (2008). "Standard specification for coal fly ash and raw or calcined natural pozzolan for use in concrete." ASTM C618-08a, West Conshohocken, PA.

ASTM. (2014). "Standard specification for portland cement." ASTM C150-14, West Conshohocken, PA.

Bensted, J. (1999). "Thaumasite-Background and nature in deterioration of cements, mortars and concretes." Cem. Concr. Compos., 21(2), 117-121.

Bensted, J. (2003). "Thaumasite-Direct, woodfordite and other possible formation routes." Cem. Concr. Compos., 25(8), 873-877.

Binifi, H., Kapur, S., Arocena, J., and Kaplan, H. (2012). "The sulfate resistance of cements containing red brick dust and ground basaltic pumice with sub-microscopic evidence of intra-pore gypsum and ettringite as strengtheners." Cem. Concr. Compos., 34(2), 279-287.

Blondiau, L. (1961). "Considerations diverses relatives à l'essai de resistance chimique au sulfate de calcium suivant le processus Le ChatelierAnsttet." Rev. Mat. Constr. Trav. Pub., 546, 120-189.

Calleja, J., and Aguanell, M. (1980). "Considerations about the Le Chatelier-Ansttet test and the behavior of cements in front of sulfate attack." Mater. Constr., 30(179), 39-48.

Collet, G., Crammond, N. J., Swamy, R. N., and Sharp, J. H. (2004). "The role of carbon dioxide in the formation of thaumasite." Cem. Concr. Res., 34(9), 1599-1612.

Crammond, N. J. (2003). "The thaumasite form of sulfate attack." Cem. Concr. Compos., 25(8), 809-818.

Damidot, D., Barnett, S. J., Glasser, F. P., and Macphee, D. E. (2004a). "Investigation of the $\mathrm{CaO}-\mathrm{Al}_{2} \mathrm{O}_{3}-\mathrm{SiO}_{2}-\mathrm{CaSO}_{4}-\mathrm{CaCO}_{3}-\mathrm{H}_{2} \mathrm{O}$ system at $25^{\circ} \mathrm{C}$ by thermodynamic calculation." $A d v$. Cem. Res., 16(2), 69-76.

Damidot, D., Barnett, S. J., Glasser, F. P., and Macphee, D. E. (2004b). "Investigation of the $\mathrm{CaO}-\mathrm{Al}_{2} \mathrm{O}_{3}-\mathrm{SiO}_{2}-\mathrm{CaSO}_{4}-\mathrm{CaCO}_{3}-\mathrm{H}_{2} \mathrm{O}$ system at $25^{\circ} \mathrm{C}$ by thermodynamic calculation." Adv. Cem. Res., 16(2), 69-76.

de Silva, P. S., and Glasser, F. P. (1990). "Hydration of cements based on metakaolin. Thermochemistry." Adv. Cem. Res., 3(12), 167-177.

de Silva, P. S., and Glasser, F. P. (1993). "Phase relation in the system $\mathrm{CaO}-\mathrm{Al}_{2} \mathrm{O}_{3}-\mathrm{SiO}_{2}-\mathrm{H}_{2} \mathrm{O}$ relevant to metakaolin-calcium hydroxide hydration." Cem. Concr. Res., 23(3), 627-639.

Frías, M., García, R., Vigil, R., and Ferreiro, S. (2008a). "Calcination of art paper sludge waste for the use as a supplementary cementing material." Appl. Clay Sci., 42(1-2), 189-193.

Frías, M., Rodríguez, O., Vegas, I., and Vigil, R. (2008b). "Properties of calcined clay waste and its influence on blended cement behavior." J. Am. Ceram. Soc., 91(4), 1226-1230.

García, R., Vigil de la Villa, R., Rodríguez, O., and Frías, M. (2010). "Study of hydrated phases present in calcined paper sludge (metakaolinite)/ saturated $\mathrm{CaO}$ dissolution system cured at $40^{\circ} \mathrm{C}$ and 28 days of reaction." Mater. Sci. Eng., 527(16-17), 3936-3941.

García, R., Vigil de la Villa, R., Vegas, I., Frías, M., and Sánchez de Rojas, M. I. (2008). "The pozzolanic properties of paper sludge waste." Constr. Build. Mater., 22(7), 1484-1490.

Liu, Z., Deng, D., de Schutter, G., and Yu, Z. (2013). "The effect of $\mathrm{MgSO}_{4}$ on thaumasite formation." Cem. Concr. Compos., 35(1), 102-108.

Martín-Luengo, M. P. (1997). "Behaviour in sulfatic resistance and mechanical strengths of some crystalline and amorphous components of fly ashes." Ph.D. dissertation, Autonomous Univ. of Madrid, Spain.

Mehta, P. K. (1983). "Pozzolanic and cementitious by-products as mineral admixtures for concrete-A critical review." Proc., 1st Int. Conf. ACI SP 79, American Concrete Institute, Farmington Hills, MI, 1-46.

Mehta, P. K., and Monteiro, P. (1993). Concrete: Structure, properties and materials, Prentice Hall, NJ.

Mejía, M. (1997). "Contribution to the analytical and physical-chemical study of the system: Portland cements-pozzolans-GGBS-chloridewater (at $20 \pm 3^{\circ} \mathrm{C}$ )." Ph.D. dissertation, Complutense Univ. of Madrid, Madrid, Spain.

Mejía, R., Delvasto, S., and Talero, R. (2003). "Chloride diffusion measured by a modified permeability test in normal and blended cements." Adv. Cem. Res., 15(3), 113-118.

Ministerio de Fomento. (2008). "Instrucción para la recepción de cementos." $R C$-08, Madrid, Spain.

Ministerio de Obras Poblicas. (1975). "Pliego de prescripciones técnicas generales para la recepción de cementos." $R C$-75, Madrid, Spain.

Murat, R. (1983a). "Hydration reaction and hardening of calcined clays and related minerals. I: Preliminary investigation on metakaolinite." Cem. Concr. Res., 13(2), 259-266.

Murat, R. (1983b). "Hydration reaction and hardening of calcined clays and related minerals. II: Influence of mineralogical properties of the raw-kaolinite of the reactivity of metakaolinite." Cem. Concr. Res., 13(4), 511-518.

Murat, R., and Comel, C. (1983). "Hydration reaction and hardening of calcined clays and related minerals. III: Influence of calcination process of kaolinite on mechanical strengths of hardened metakaolinite." Cem. Concr. Res., 13(5), 631-637.

Nobst, P., and Stark, J. (2003). "Investigations on the influence of cement type on thaumasite formation." Cem. Concr. Compos., 25(8), 899-906.

Rahhal, V. (2002). "Characterization of pozzolanic additions by conduction calorimetry." Ph.D. dissertation, Technical Univ. of Madrid, Madrid, Spain.

Rahhal, V., Bonavetti, V., Trusilewicz, L., Pedrajas, C., and Talero, R. (2012). "Role of the filler on portland cement hydration at early ages." Constr. Build. Mater., 27(1), 82-90.

Rahhal, V., Cabrera, O., Delgado, A., Pedrajas, C., and Talero, R. (2010). "C4AF ettringite and calorific synergic effect contribution." J. Therm. Anal. Calorim., 100(1), 57-63.

Rahhal, V., Cabrera, O., Talero, R., and Delgado, A. (2007). "Calorimetry of portland cement with silica fume and gypsum additions." J. Therm. Anal. Calorim., 87(2), 331-337. 
Rahhal, V., and Talero, R. (2005). "Early hydration of portland cement with crystalline mineral additions." Cem. Concr. Res., 35(7), 1285-1291.

Rahhal, V., and Talero, R. (2009a). "Calorimetry of portland cement with silica fume, diatomite and quartz additions." Constr. Build. Mater., 23(11), 3367-3374.

Rahhal, V., and Talero, R. (2009b). "Fast physics-chemical and calorimetric characterization of fly ash." J. Therm. Anal. Cal., 96(2), 369-374.

Rahhal, V., and Talero, R. (2010). "Fast physics-chemical and calorimetric characterization of natural pozzolans and other aspects." J. Therm. Anal. Cal., 99(2), 479-486.

Rahhal, V., and Talero, R. (2014). "Very early age detection of ettringite from pozzolan origin." Constr. Build. Mater., 53, 674-679.

Resmini, C., et al. (2012). "Production of metakaolin from industrial cellulose waste." J. Therm. Anal. Calorim., 109(3), 1341-1345.

Rodríguez, O., Frías, M., and Sánchez de Rojas, M. I. (2008). "Influence of the calcined paper sludge on the development of hydration heat in blended cement mortars." J. Therm. Anal. Calorim., 92(3), 865-871.

Sims, I., and Huntley, S. A. (2004). "The thaumasite form of sulfate attack -Breaking the rules." Cem. Concr. Compos., 26(7), 837-844.

Skaropoulou, A., Tsivilis, S., Kakali, G., Sharp, J. H., and Swamy, R. N. (2009). "Thaumasite form of sulfate attack in limestone cement mortars: A study on long time efficiency of mineral admixtures." Constr. Build. Mater., 23(6), 2338-2345.

Talero, R. (1986) "Contribution of the analytical and physical-chemistry of the ternary system: Pozzolanic cements-gypsum-water." Ph.D. thesis, Complutense Univ. of Madrid, Madrid, Spain.

Talero, R. (1989). "Los cementos portland de moderada resistencia sulfática. Métodos acelerados de ensayo para determinarla. Bases para su caracterización y control.” IETcc-CSIC Publications, Madrid, Spain.

Talero, R. (1990). "Qualitative analysis of natural pozzolans, fly ashes and blast furnace slags by XRD." J. Mater. Civ. Eng., 10.1061/(ASCE) 0899-1561(1990)2:2(106), 106-115.

Talero, R. (2002). "Kinetochemical and morphological differentiation of ettringites by metakaolin, portland cements and the Le ChatelierAnsttet test." Cem. Concr. Res., 32(5), 707-717.

Talero, R. (2005). "Performance of metakaolin and portland cements in ettringite formation as determined by ASTM C 452-68. Kinetic and morphological differences." Cem. Concr. Res., 35(7), 1269-1284.

Talero, R. (2007). "Performance of metakaolin and portland cements in ettringite formation as determined by the Le Chatelier-Ansttet test:
Kinetic and morphological differences and new specification." Silicates Industriels, 72(11), 191-204.

Talero, R. (2009). "Kinetic and morphological differentiation of ettringites by metakaolin, portland cements and ASTM C 452-68 test. II Morphological differentiation by SEM and XRD analysis." Mater. Constr., 59(293), 35-51.

Talero, R. (2010). "Expansive synergic effect of ettringite from pozzolan and from OPC, co-precipitating in a common plaster-bearing solution. I: By cement pastes and mortars." Constr. Build. Mater., 24(9), 1779-1789.

Talero, R. (2011a). "Co-precipitation of ettringite of rapid and slow formation. Consequence: Expansive synergic effect. Its demonstration by mortars and concretes." Mater. Constr., 61(303), 327-352.

Talero, R. (2011c). "Expansive synergic effect of ettringite from pozzolan and from OPC, co-precipitating in a common plaster-bearing solution. II: Fundamentals, explanation and justification." Constr. Build. Mater., 25(3), 1139-1158.

Talero, R. (2012). "Synergic effect of Friedel's salt from pozzolan and from OPC co-precipitating in a chloride solution." Constr. Build. Mater., 33, $164-180$.

Talero, R. (2013). "Performance of silicic pozzolans and portland cements in front of sulfate attack determined by ASTM C 452-68." Mater. Constr., 63(310), 159-193.

Talero, R., et al. (2011). "Comparative and semi-quantitative XRD analysis of Friedel's salt originating from pozzolan and portland cement." Constr. Build. Mater., 25(5), 2370-2380.

Talero, R., Pedrajas, C., Delgado, A., and Rahhal, V. (2009). "Re-use of incinerated agro-industrial waste as pozzolanic addition. Comparison with Spanish silica fume." Mater. Constr., 59(296), 53-89.

Talero, R., and Rahhal, V. (2009). "Calorimetric comparison of portland cements containing silica fume and metakaolin. Is silica fume, like metakaolin, characterized by pozzolanic activity that is more specific than generic?" J. Therm. Anal. Calorim., 96(2), 383-393.

Taylor, H. F. W. (1990). Cement chemistry, Academic Press, London.

Tosum, K., Felekoğlu, B., Baradan, B., and Akim Altun, I. (2009). "Effects of limestone replacement ratio on the sulfate resistance of portland limestone cement mortars exposed to extraordinary high sulfate concentrations." Constr. Build. Mater., 23(7), 2534-2544.

Trusilewicz, L., Fernandez Martinez, F., Rahhal, V., and Talero, R. (2012). "TEM and SAED characterization of metakaolin. Pozzolanic activity." J. Am. Ceram. Soc., 95(9), 2989-2996. 